\title{
Atrazine Inhalation Worsen Pulmonary Fibrosis Regulating the Nuclear Factor- Erythroid 2-Related Factor (Nrf2) Pathways Inducing Brain Comorbidities
}

\author{
Ramona D'Amico Francesco Monaco $^{b}$ Roberta Fusco ${ }^{a}$ Rosalba Siracusa ${ }^{a}$ \\ Daniela Impellizzeria Alessio Filippo Peritore ${ }^{a}$ Rosalia Crupic Enrico Gugliandoloc \\ Salvatore Cuzzocrea ${ }^{a, d} \quad$ Rosanna Di Paola ${ }^{a}$ Tiziana Genovese ${ }^{a} \quad$ Marika Cordaro ${ }^{b}$ \\ aDepartment of Chemical, Biological, Pharmaceutical and Environmental Sciences, University of \\ Messina, Messina, Italy, bepartment of Biomedical, Dental and Morphological and Functional Imaging \\ University of Messina, Messina, Italy, 'Department of Veterinary Sciences, University of Messina, \\ Messina, Italy, dDepartment of Pharmacological and Physiological Science, Saint Louis University \\ School of Medicine, Saint Louis, MO, USA
}

\section{Key Words}

Oxidative stress $\bullet$ Inflammation $\cdot$ Atrazine $\cdot$ Fibrosis $•$ Behavioral alteration

\begin{abstract}
Background/Aims: Pulmonary fibrosis can be caused by genetic abnormalities, autoimmune disorders or exposure to environmental pollutants. All these causes have in common the excessive production of oxidative stress species that initiate a cascade of molecular mechanism underlying fibrosis in a variety of organs, including lungs. The chemical name of Atrazine (ATR) is 6-chloro-N-ethyl- $\mathrm{N}^{\prime}$-(1-methylethyl)-1,3,5-triazine-2,4-diamine, and it is the most commonly used broad-spectrum herbicide in agricultural crops. Additionally, Bleomycin is a chemotherapeutic agent often used for different lymphoma with a seriously pulmonary complication. The most accredited hypothesis that may explain the mechanism of toxicity induced by ATR or bleomycin is exactly the production of reactive oxygen species (ROS) that leads to an unbalance in the physiological anti-oxidant system. However, until today, nobody has investigated the effect of ATR exposure during pulmonary fibrosis. Methods: Mice were subject to ATR exposure, to bleomycin injection or to both. At the end of experiment, the lungs and blood were collected. Additionally, we analyzed by different test such as open field, pole and rotarod test or other we investigated the effects of ATR or bleomycin exposure on behavior. Results: Following ATR or bleomycin induction, we found a significant increase in
\end{abstract}

R. D'Amico, F. Monaco and R. Fusco contributed equally to this work.

M. Cordaro and T. Genovese share senior authorship.

Rosanna Di Paola

and Salvatore Cuzzocrea
Department of Chemical, Biological, Pharmaceutical and Environmental Sciences, University of Messina, Viale Ferdinando Stagno D'Alcontres 31, 98166 Messina (Italy) E-Mail dipaolar@unime.it; salvator@unime.it 


\section{Cellular Physiology Cell Physiol Biochem 2021;55:704-725

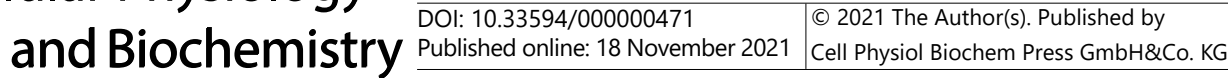 \\ D'Amico et al.: Atrazine Worsen Pulmonary Fibrosis}

lung damage, fibrosis, and oxidative stress. This condition was significantly worsened when the animals injected with bleomycin were also exposed to ATR. Additionally, we observed significant motor and non-motor impairment in animals exposed to ATR. Conclusion: Our study demonstrates that ATR exposure, decrease nuclear factor-erythroid 2-related factor (Nrf2) pathways in both lung and brain.

\section{Introduction}

The lung is subjected to a higher oxygen tension than the rest of the body [1]. Exogenous oxidants and pollutants increase oxidant production by activating inflammatory cells, which produces free radicals. In these conditions, several significant reactive oxygen species (ROS) are produced endogenously. The superoxide radical, hydrogen peroxide $\left(\mathrm{H}_{2} \mathrm{O}_{2}\right)$, and the hydroxyl radical are among them [2]. The interactions of superoxide with nitric oxide can also produce a number of reactive nitrogen species (RNS), such as peroxynitrite (NO) [3].

Different studies suggest that oxidant-antioxidant imbalances in the lower respiratory tract play a critical role in the pathogenesis of idiopathic pulmonary fibrosis (IPF). IPF is an example of an idiopathic disease; however, it can also be caused by genetic abnormalities, autoimmune disorders or exposure to environmental pollutants (EP) [4]. The existence of altered antioxidant levels in the lungs of patients with IPF indicates the occurrence of an oxidant-antioxidant imbalance [5-7]. Manganese-SOD (Mn-SOD), catalase (CAT), glutathione peroxidase (GPx) and heme-oxygenase 1 (HO-1) are some of the enzymes involved during oxidative stress condition. Although a reduction in antioxidant capacity is likely to increase oxidative stress, the observed antioxidant elevations are most likely an attempt to compensate for the increased oxidative stress in the lungs. It is obvious, however, that the usual redox balance in the lungs of people with IPF is disrupted [8-10].

Human exposure to environmental polluntats such as endocrine disrupting chemicals (EDCs) has attracted considerable attention in recent years as a result of epidemiological and experimental investigations linking them to altered human health. In the past, when EDCs were discovered, it was thought that they could only interfere with the endocrine system, and, for this reason, they were termed endocrine disrupting (ED), but today, this definition is considered outdated; in fact, different studies conducted on animals as well as clinical observations and epidemiological studies have indicated the role of endocrine disruptors in affecting the reproductive systems, prostate, breast, liver, thyroid, metabolism and lungs $[11,12]$. EDs can be classified into three major groups: (i) food contact materials, such as bisphenol A; (ii) chemicals in products, such as phthalates or parabens; and (iii) pesticides, such as Atrazine (ATR) $[13,14]$.

The chemical name of ATR is 6-chloro-N-ethyl-N'-(1-methylethyl)-1,3,5-triazine-2,4diamine, and it is the most commonly used broad-spectrum herbicide in agricultural crops [15]. The most accredited hypothesis that may explain the mechanism of toxicity induced by ATR is that the production of reactive oxygen species (ROS) leads to an unbalance in the physiological anti-oxidant system involving nuclear factor-erythroid 2-related factor 2 (Nrf2) expression, superoxide dismutase (SOD), catalase (CAT) and glutathione [15-23]. Different studies demonstrated that, Nrf2 plays essential roles in protection against oxidantinduced pulmonary inflammation and fibrosis [24-27]. It is probably due to the fact that Nrf2 has an advantage over a single antioxidant molecule for the treatment of acute lung injury and pulmonary fibrosis, since Nrf2 coordinately induces a variety of self-defense genes, including antioxidant and phase II enzymes [28].

ATR contamination has been linked to many different serious health issues, such as dermatologic diseases, neurologic conditions, cancer and respiratory problems [29-39]. In particular, the Agricultural Health Research (AHS), one of the most important studies on respiratory pathologies, found a correlation between wheeze and Atrazine exposure [40]. However, it is critical to investigate the effects of occasional air exposure on the lungs when considering that some ATR is released into the atmosphere as a result of its preparation, 


\section{Cellular Physiology Cell Physiol Biochem 2021;55:704-725 \\ \begin{tabular}{ll|l} 
and Biochemistry & $\begin{array}{l}\text { DOl: 10.33594/000000471 } \\
\text { Published online: } 18 \text { November } 2021\end{array}$ & $\begin{array}{l}\text { O 2021 The Author(s). Published by } \\
\text { Cell Physiol Biochem Press GmbH\&Co. KG }\end{array}$ \\
\cline { 2 - 3 }
\end{tabular} \\ D'Amico et al.: Atrazine Worsen Pulmonary Fibrosis}

manufacturing, and disposal; that it also enters the environment through the loss of applied herbicide until it enters the soil surface; the particle distribution of ATR-containing dust; and that ATR volatilization after application to fields has been estimated to be up to $14 \%$ of the applied volume.

However, to date, the relationship between ATR exposure and PF has not been explored. PF can be easily and experimentally reproduced and developed by bleomycin administration. Its usage is justified by the fact that fibrosis is one of the most serious side effects of bleomycin treatment in humans. Bleomycin is thought to work by generating single- and double-strand DNA breaks in cells, stopping the cell cycle. In particular, the intratracheal instillation of bleomycin leads to a massive inflammatory reaction marked by the overexpression of pro-inflammatory cytokines and ROS, and alteration in SOD, CAT and GSH activity followed by increased levels of pro-fibrotic markers [41]. Recent studies additionally focused their attention on the role played by Nrf2 expression during $\mathrm{PF}$, showing that it plays a particularly important role in the progression of this pathology $[28,42-50]$. Additionally, in light of the fact that some studies have recently demonstrated strong connections between common extrapulmonary brain-related comorbidities, such as depression, anxiety and cognitive problems [51-59], we also evaluated for the first time the impact of ATR exposure on behavioral changes in animals subjected or not to bleomycin administration.

There are few studies in the literature evaluating the effects of pollutants on the worsening of PF and none regarding the effect of ATR on pulmonary fibrosis.

In this context, we evaluated the effects of ATR exposure in an animal model of bleomycin-induced pulmonary fibrosis to evaluate the impact of EDc on histological damage, cell recruitment, inflammation, oxidative stress and behavioral alterations.

\section{Materials and Methods}

\section{Animals}

CD1 male mice (8-week-old, 18-24g) were acquired from Envigo (Milan, Italy) and located in a controlled environment. The University of Messina Review Board for animal care (OPBA) approved the study (Ethical Code: 266/2021-PR). All animal experiments complied with the new Italian regulations (D.Lgs 2014/26), EU regulations (EU Directive 2010/63) and the ARRIVE guidelines.

\section{Experimental Design and Groups}

Bleomycin administration was performed as previously described [41, 60]. In detail, bleomycin sulphate $(1 \mathrm{mg} / \mathrm{kg}$ body weight) was delivered by a single intratracheal administration. A volume of $100 \mu \mathrm{L}$ was injected at end-expiration to guarantee delivery to the distal airways. This was immediately followed by $300 \mu \mathrm{L}$ of air. Additionally, ATR aerosol was prepared dissolving $25 \mathrm{mg}$ of ATR in a vehicle formed by saline with $10 \%$ of DMSO and given pro kilo through a Lovelace nebulizer (In-Tox Products, Albuquerque, NM) as previously described by D'Amico et al. [61-63].

Mice were randomly divided into groups:

(I) Sham: animals that were exposed to the vehicle (saline with $10 \%$ of DMSO).

(II) ATR: animals that were exposed to $25 \mathrm{mg}$ of ATR for 14 days.

(III) Bleomycin group: animals that receive one injection of bleomycin.

(IV) Bleomycin+ATR group: animals that were exposed to $25 \mathrm{mg}$ di ATR for 14 days after a single injection of bleomycin.

At the end of experiment, mice were sacrificed, and lung and brain tissue, bronchoalveolar lavage fluid (BALF) and blood samples were collected for histology and biochemical analysis as previously described $[18,20,21,64-66]$. The dose of ATR was chosen based on another previously study, but for the first time, we decided to administer ATR not via oral gavage but via aerosol because our knowledge of the effects of ATR on the lungs remains poor [67-69]. 


\section{Cellular Physiology Cell Physiol Biochem 2021;55:704-725 \\ \begin{tabular}{l|l|l}
\hline DOI: 10.33594/000000471 & ( 2021 The Author(s). Published by
\end{tabular} \\ and Biochemistry Published online: 18 November 2021 Cell Physiol Biochem Press GmbH\&Co. KG \\ D'Amico et al.: Atrazine Worsen Pulmonary Fibrosis}

\section{Measurement of Lung Edema}

At the end of the experiment, wet lung weights were recorded. The lungs were subsequently dried for $48 \mathrm{~h}$ at $180^{\circ} \mathrm{C}$ and then weighed again. The water content of the lungs was calculated as the ratio of the wet:dry weight of the tissue $[41,60,70,71]$.

Bronchoalveolar Lavage (BAL)

At the end of experiment, mice were euthanized, and the tracheas were cannulated to perform the lavage for cell counting, as previously described $[41,60,70,71]$. Additionally, from BAL, we analyzed the total protein content using a DC Protein Assay kit (Bio-Rad Laboratories, Hercules, CA, USA) as previously described $[72,73]$.

Western Blot Analysis of Cytosolic and Nuclear Extracts

Extracts from cytosol and nucleus from lung and brain were prepared as previously mentioned [74, 75]. The following primary antibodies were used: anti-NRF-2 (1-500, Santa Cruz Biotechnology, Heidelberg, Germany, \#sc-365949), anti-heme oxygenase 1 (HO-1; 1-500, Santa Cruz Biotechnology, Heidelberg, Germany, \#sc-136960) in $1 \times$ PBS, 5\% w/v non-fat dried milk, and $0.1 \%$ Tween-20 at $4{ }^{\circ} \mathrm{C}$ overnight. For the cytosolic and nuclear fraction, blots were also probed with $\beta$-actin and lamin $\mathrm{A} / \mathrm{C}$ protein to ensure that they were filled with equivalent amounts of proteins (1:500; Santa Cruz Biotechnology). Signals were detected as previously described in our works [70, 76-82].

\section{Histopathological Evaluation with Hematoxylin/Eosin and Masson Trichrome}

Lungs were dehydrated, embedded in paraffin and stained in hematoxylin/eosin (H/E) or Masson Trichrome and analyzed using light microscopy LeicaDM6 connected to an Imaging system (LasX Navigator) and were blindly scored by two investigators without knowledge of the experimental groups. The severity of lung damage and fibrosis was assessed according to the method of Ashcroft et al. [60, 83-86].

\section{Immunohistochemical evaluation of $\alpha$-Smooth Muscle Actin ( $\alpha$-sma)}

Lung sections were incubated with anti- $\alpha$-sma antibody (1:250, Santa Cruz Biotechnology) as previously described by Cordaro et al. $[77,84]$. Sections were then incubated with peroxidase-conjugated bovine anti-mouse immunoglobulin G (IgG) secondary antibody or peroxidase-conjugated goat anti-rabbit IgG (1:2,000 Jackson Immuno Research, West Grove, PA, USA). Specific marking was revealed with a biotinconjugated goat anti-rabbit IgG or the biotin-conjugated goat anti-mouse IgG and avidin-biotin peroxidase complex (Vector Laboratories, Burlingame, CA, USA). The digital images were analyzed as previously made in our laboratory [87-89]. All immunohistochemical analyses were carried out by two observers blinded to the treatment [90].

\section{Evaluation of Tissue Lipid Peroxidation}

Malonaldehyde (MDA) levels in lung tissue were assessed as previously described at the end of the experiments. Briefly, after homogenization, MDA absorbances was measured at $650 \mathrm{~nm}$ using a spectrophotometer [91-93].

\section{Assessment of anti-oxidant system}

The SOD activity assay was measured following the method described by Marklund and Marklund at $420 \mathrm{~nm}$ [94]. The results are presented as SOD units/mg protein. Moreover, the activity of CAT was assessed following the method of Aebi in terms of mmoles of hydrogen peroxide $\left(\mathrm{H}_{2} \mathrm{O}_{2}\right)$ consumed per min per mg of protein [95]. The results are presented as CAT units/mg protein. Furthermore, the level of the nonenzymatic cellular anti-oxidant glutathione was measured following the method of Moron et al. [96-98]. The results are presented as GSH units/mg protein.

\section{Assessment of Cytokine Production}

ELISA kits were used to test pro-inflammatory cytokine production, in particular, that of IL-1 $\beta$, IL-6 and TNF- $\alpha$, in BALF at the end of experiment, as previously described [99]. The manufacturer's manuals provide specific instructions for the test procedure. 


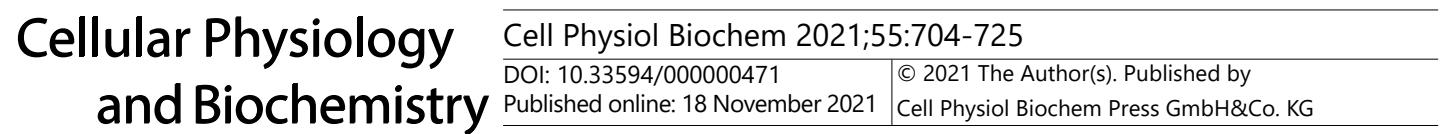 \\ D'Amico et al.: Atrazine Worsen Pulmonary Fibrosis}

Behavioral testing

In another set of experiments, the same group previously described were subjected to behavioral tests on days 1 and 14 of the experiment. Mice were transferred to the behavior testing room 30 min prior to beginning the first trial to habituate to its conditions. Animals familiarized to the apparatus before every recording based on the behavioral test and were subjected to keep the condition as uniform as possible.

Three different reliable expert observers blinded to the injury status of the animals conducted the behavioral tests. The tests are described below.

\section{Pole Test (PT)}

A pole test (PT) was performed to detect motor alteration, such as bradykinesia, as previously described $[100,101]$. Briefly, mice, were positioned with their head oriented upward on top of the pole and after the training the time required for the animals to orient themselves in a downward direction (time to $\mathrm{T}$ turn) and to descend to the base of the pole (total time) was recorded for five different trials.

\section{Rotarod Test (RT)}

Motor activity was assessed with rotary rod apparatus using a protocol previously described [102, 103]. In brief, after the training sessions, animal was placed back on the drum immediately after falling up to five times in one session.

\section{Catalepsy Test (CT)}

Catalepsy, demarcated as a reduced capability to start movement and a failure to correct posture, was measured as previously described $[104,105]$. In particular, after the training the length of time the mice maintained this position was recorded.

\section{Elevated Pluz Maze (EPM)}

The Elevated Pluz Maze (EPM) test was performed to evaluated the anxiety state as described previously $[106,107]$. Briefly, after the training session, the number of entries into each arm and the number of crossings were recorded.

\section{Open field test (OFT)}

Locomotor activity and anxiety-like behavior were monitored by the OFT. After a training session, each mouse was gently placed in the center of the box, and activity was scored as a line crossing when a mouse removed all four paws from one square and entered another [108, 109].

\section{Barnes Maze (BM)}

The BM is a validated test often used to assess spatial learning and memory in rodents. After the training session, the performance is measured by the number of errors the rodent makes, and the rate of decline in the number of errors per trial is calculated to represent a learning curve [110].

\section{Materials}

Unless otherwise stated, all compounds were purchased from Sigma-Aldrich (Milan, Italy).

\section{Statistical Evaluation}

In this study, the data are expressed as the average \pm SEM and represent at least 3 experiments carried out on different days. For in vivo studies, $\mathrm{N}$ represents the number of animals used. The number of animals used for in vivo studies was determined by G * Power 3.1 software (Heinrich-Heine-Universität Düsseldorf, Düsseldorf, Germany). Data were analyzed by one-way ANOVA followed by a Bonferroni post-hoc test for multiple comparisons. Data were analyzed by an experienced histopathologist, and all the studies were performed without knowledge of the treatments. 


\section{Cellular Physiology Cell Physiol Biochem 2021;55:704-725 \\ \begin{tabular}{ll|l} 
and Biochemistry & $\begin{array}{l}\text { DOl: 10.33594/000000471 } \\
\text { Published online: } 18 \text { November } 2021\end{array}$ & $\begin{array}{l}\text { C 2021 The Author(s). Published by } \\
\text { Cell Physiol Biochem Press GmbH\&Co. KG }\end{array}$ \\
\cline { 2 - 3 }
\end{tabular} \\ D'Amico et al.: Atrazine Worsen Pulmonary Fibrosis}

\section{Results}

\section{Exposure to ATR worsens bleomycin-induced histological damage}

At the end of experiment, the lungs were removed, fixed, embedded in paraffin and stained with hematoxylin and eosin in order to evaluate their histological alterations. Fig. $1 \mathrm{~B}, \mathrm{C}$ shows that exposure to ATR and the administration of bleomycin alone were able to induce significant alterations in the lung architecture, as highlighted in inflamed areas with notable presence of neutrophils and thickening of the lung tissue when compared to the sham group (Fig. 1A). The group of animals treated simultaneously with ATR and BLM (Fig. 1D, Ashcroft score 1E) showed greater histological changes than those of the groups treated with single molecules.

Additionally, ATR and BLM administration caused an increase in the wet:dry lung weight ratio due to infiltration of inflammatory cells and edema when compared to sham-operated mice. Moreover, in this case, the group of animals treated simultaneously with ATR and BLM showed a significantly greater increase than that in the groups treated with single molecules (Fig. 1F).

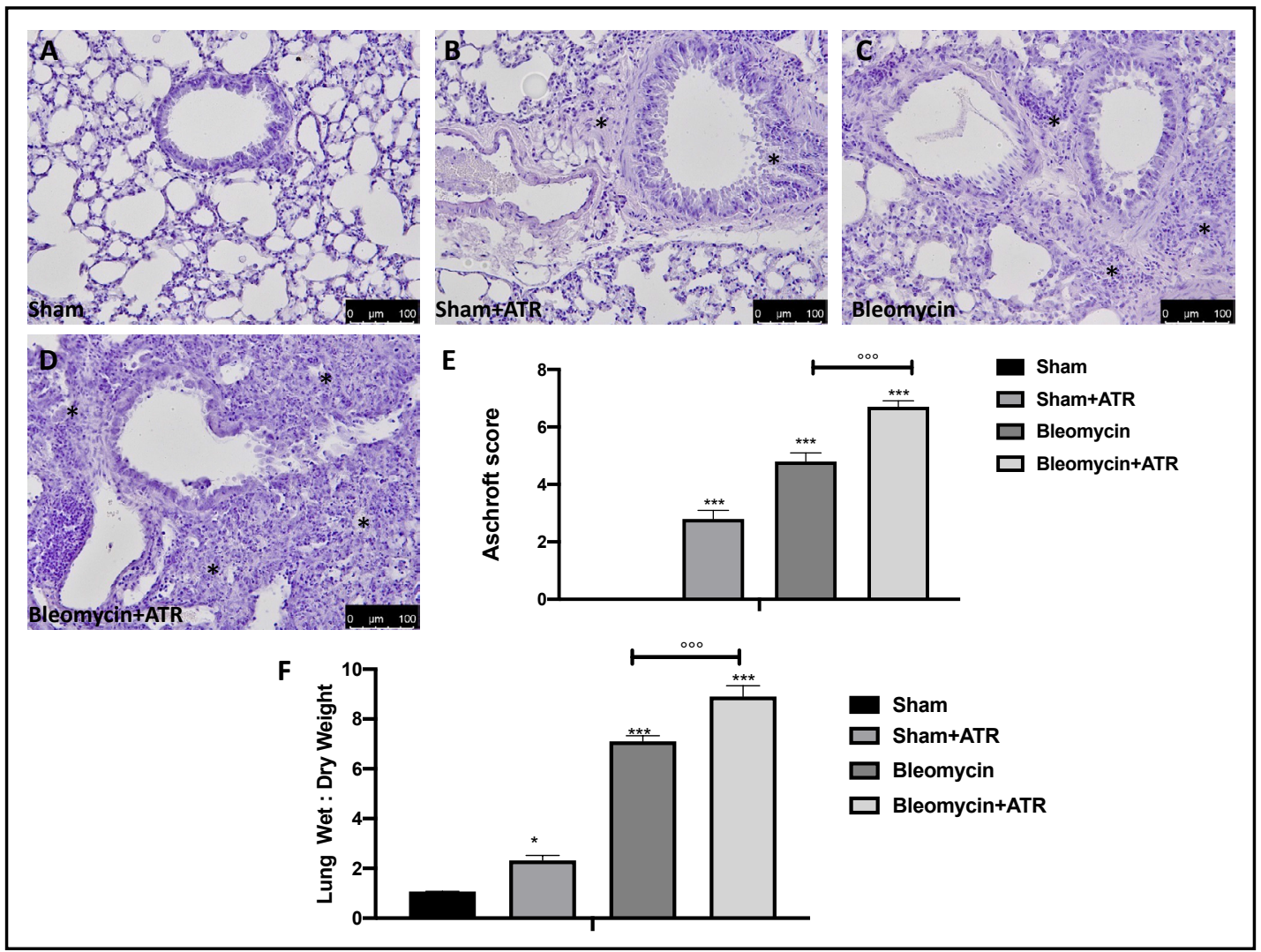

Fig. 1. Exposure to ATR worsens bleomycin-induced histological damage. Bleomycin injection induced significant pulmonary damage as well as an increase in the lung wet:dry ratio that were significantly worsen by the exposure to ATRazine. Representative photos of lung tissue slices stained by H/E. (A) Sham, (B) ATRazine, (C) Bleomycin, (D) Bleomycin+ATRazine, and (E) Lung alterations were assessed according to the Ashcroft score; (F) wet:dry lung weight ratio. Slides were observed by two investigators in a blinded fashion. The photos are demonstrative of at least three experiments achieved on different experimental days. Data are expressed as the mean \pm SEM of $n=5$ animals for each group. ${ }^{*} p<0.05$ vs. Sham; ${ }^{* * *} \mathrm{p}<0.001$ vs. Sham; ${ }^{\circ \circ} \mathrm{p}<0.001$ Bleomycin+ATR vs. Bleomycin. 


\section{Exposure to ATR increases bleomycin-induced inflammatory cell migration}

Early bleomycin damage to the lung is characterized by damage to the endothelial lining of small vessels and capillaries, accompanied by vascular congestion and increased microvascular permeability, which leads to an inflammatory response [111]. An increase in BAL cellularity was observed at the end of the experiment via cytospin analysis. We found that after ATR exposure or BLM administration, there was an increase in cellular density in BAL (Fig. 2A-E for total cells, neutrophils, lymphocytes and macrophages, respectively) as well as an increase in protein content (Fig. 2E) compared to the sham group. In line with the increased infiltration of inflammatory cells observed in the histology, we found a more significant increase in cellular density in the group simultaneously exposed to ATR and BLM in all parameters evaluated.

\section{Exposure to ATR worsens bleomycin-induced fibrosis}

Masson's trichrome staining and immunohistochemical localization of $\alpha$-SMA were adopted to examine the pulmonary fibrosis in lung tissue. Histopathological results showed that the ATR exposure (Fig. 3B) and BLM (Fig. 3C) significantly induce fibrotic lesions and collagen accumulation in the lungs of mice when compared to the sham group (Fig. 3A).

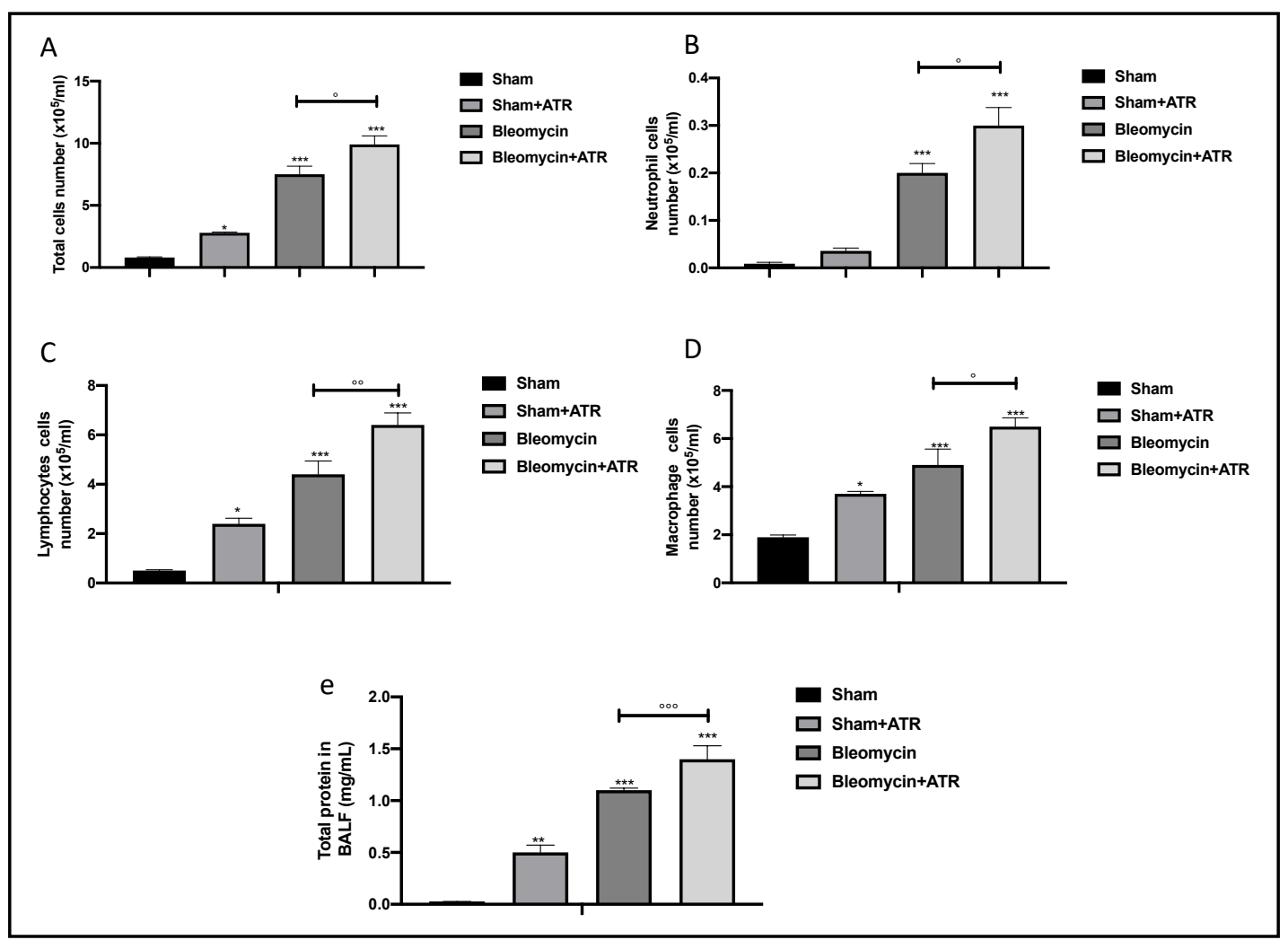

Fig. 2. Exposure to ATR increases bleomycin-induced inflammatory cell migration. Total (A) and differential cell counts (B for neutrophils; C for lymphocytes; D for macrophages) in bronchoalveolar lavage (BAL) fluid from all groups. Total cell numbers as well as differential cell counts in BAL were significantly higher than those in controls in the Bleomycin+ATR group as well as in the group with single molecules. Simultaneous exposure to bleomycin and ATR further increased the number of cells in BAL. Moreover, the total protein concentration in BAL (E) fluid collected from the group exposed to both compounds was significantly higher than that of single molecules and the sham group. Data are expressed as the mean \pm SEM of $n=5$ animals for each group. ${ }^{*} \mathrm{p}<0.05$ vs. Sham; ${ }^{* *} \mathrm{p}<0.01$ vs. Sham; ${ }^{* * *} \mathrm{p}<0.001$ vs. Sham; ${ }^{\circ} \mathrm{p}<0.05$ Bleomycin+ATR vs. Bleomycin; ${ }^{\circ} \mathrm{p}<0.01$ Bleomycin+ATR vs. Bleomycin; ${ }^{\circ \circ} \mathrm{p}<0.001$ Bleomycin+ATR vs. Bleomycin. 


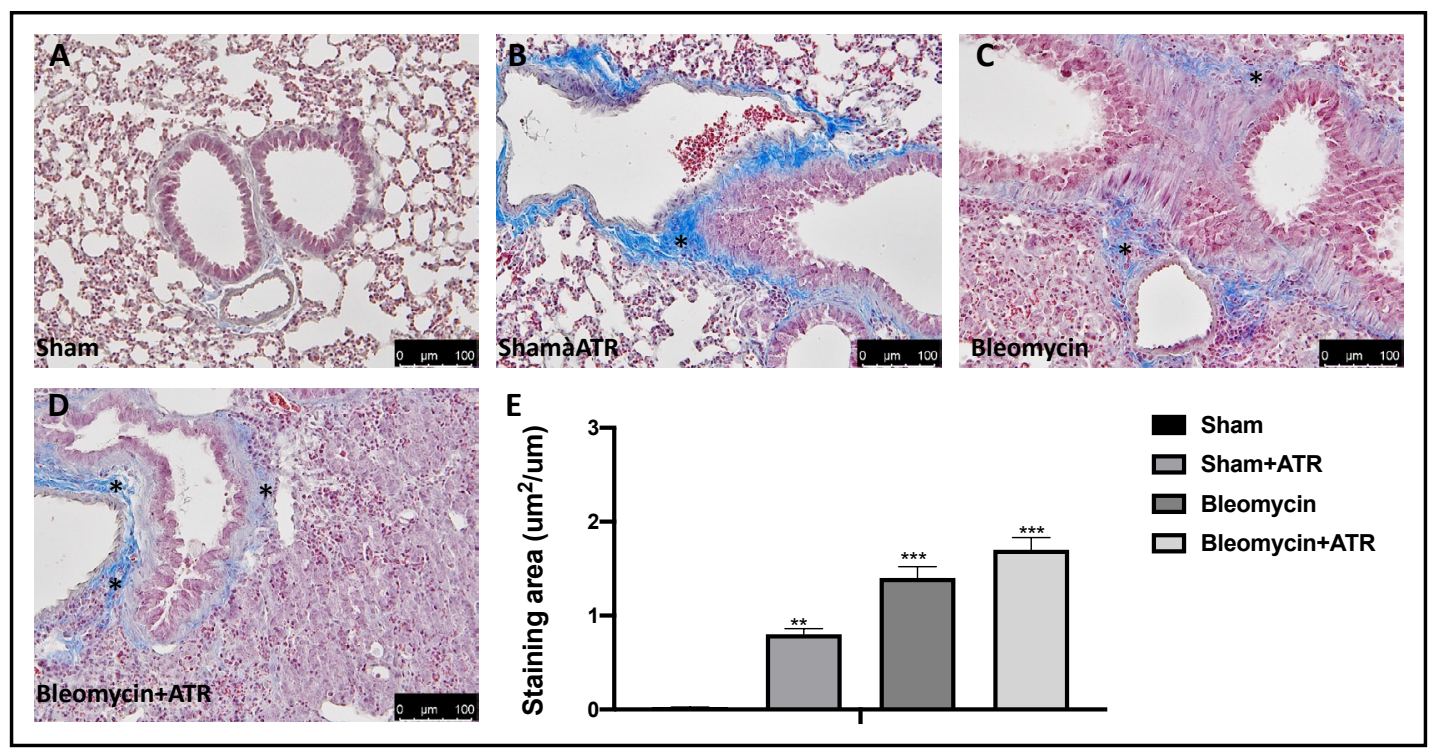

Fig. 3. Exposure to ATR worsens bleomycin-induced fibrosis. Masson trichrome staining was used to evaluate the degree of collagen deposition after exposure to bleomycin, ATR or both. Representative photos of lung tissue stained with Masson collected from (A) Sham, (B)ATRazine, (C) Bleomycin and (D) Bleomycin+ATRazine; (E) staining area. Injection of bleomycin and exposure to ATR significantly increased collagen deposition compared to that in the sham group. The photos are demonstrative of at least three experiments carried out on different experimental days. Data are expressed as the mean \pm SEM of $n=5$ animals for each group. ${ }^{* *} \mathrm{p}<0.01$ vs. Sham; ${ }^{* * *} \mathrm{p}<0.001$ vs. Sham.

Moreover, exposure to ART at the same time as the BLM injection showed greater worsening than that of the single molecules (Fig. 3D; see graph 3E). Another widely consolidated marker of fibrosis in the literature is represented by the expression of the $\alpha$-SMA protein $[60,112]$. As assumed, we found a significant staining increase in the group subjected to ATR (Fig. 4B; see graph 4E) or BLM (Fig. 4C; see graph 4E), and an even more significant increase in the group subjected to both (Fig. 4D; see graph $4 \mathrm{E}$ ) when compared to the sham group (Fig. 4A; see graph $4 \mathrm{E})$.

\section{Exposure to ATR increases bleomycin-induced pro-inflammatory cytokine release}

During bleomycin-induced inflammatory response, a key role is played by the cytokines that are capable of contributing to the fibrotic response as well as to the direct effects on fibroblast proliferation and extracellular matrix production. We found a significant increase in the BAL of IL-1 $\beta$ (Fig. 5A), IL-6 (Fig. 5B) and TNF- $\alpha$ (Fig. 5C) release in the groups subjected to ATR or BLM and a more significant increase in the group subjected to both molecules.

\section{ATR exposure worsen oxidative/nitrosative stress and lipid peroxidation}

As is well known, administration of bleomycin causes cellular toxicity via production of reactive oxygen species (ROS), which leads to serious damage to the lungs. Several previously studies demonstrated that antioxidants such as superoxide dismutase (SOD) (Fig. 6A), catalase (CAT) (Fig. 6B) and those generated by the glutathione (GSH) system (Fig. 6C) are involved in the partial protection from BLM-induced toxicity.

In our work, all of the parameters taken in consideration significantly decreased after the exposure to ATR or BLM injection, and to an extremely significant extent in the group expose to both. With the aim of investigating this alteration even further upstream, we evaluated the expression of Nrf-2 (Fig. 7A, A') and HO-1 (Fig. 7B, B') by Western blot analysis and found that these two factors, also involved in the physiological regulation of the oxidative balance of the cells, were significantly reduced following exposure to the single molecules and even more following simultaneous exposure to both. Therefore, in a similar way, the 


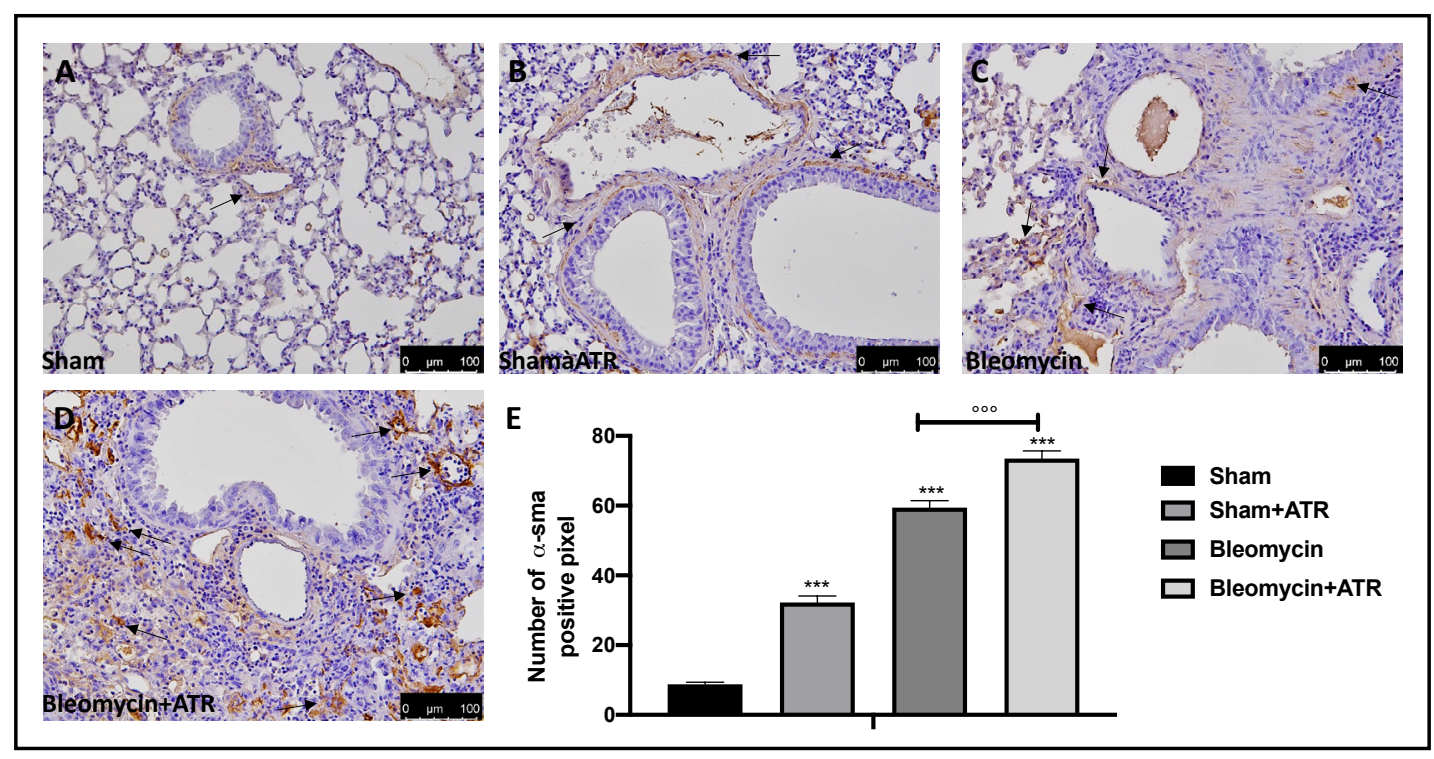

Fig. 4. Exposure to ATR increases $\alpha$-SMA expression. Immunohistochemical staining was used to investigated $\alpha$-SMA expression in the lung after exposure to bleomycin, ATR or both. Representative photos collected from (A) Sham, (B)ATRazine, (C) Bleomycin and (D) Bleomycin+ATRazine; (E) graphic representation of $\alpha$-SMA expression. Injection of bleomycin and exposure to ATR significantly increased $\alpha$-SMA expression compared to that in the sham group. Moreover, the exposure to both compounds further increased $\alpha$-SMA expression compared to that of the single molecules. The photos are demonstrative of at least three experiments carried out on different experimental days. Data are expressed as the mean \pm SEM of $n=5$ animals for each group. ${ }^{* * *} \mathrm{p}<0.001$ vs. Sham; ${ }^{\circ 00} \mathrm{p}<0.001$ Bleomycin+ATR vs. Bleomycin.

Fig. 5. Exposure to ATR increases bleomycin-induced pro-inflammatory cytokine release. IL-1 $\beta$ (A), IL-6 (B) and TNF- $\alpha$ (C) were investigated in the lung using the ELISA KIT. Instillation of bleomycin and exposure to ATR significantly increased the expression of all pro-inflammatory cytokines. Simultaneous exposure to both molecules further increased cytokine release compared to that of single molecules and the sham group. Data are expressed as the mean \pm SEM of $\mathrm{n}=5$ mice/group. ${ }^{* *} \mathrm{p}<0.01$ vs. Sham; ${ }^{* * *} \mathrm{p}<0.001$ vs. Sham; ${ }^{\circ} \mathrm{p}<0.05$ Bleomycin+ATR vs. Bleomycin; ${ }^{\circ} \mathrm{p}<0.01$ Bleomycin+ATR vs. Bleomycin; ${ }^{\circ \circ} \mathrm{p}<0.001$ Bleomycin+ATR vs. Bleomycin.

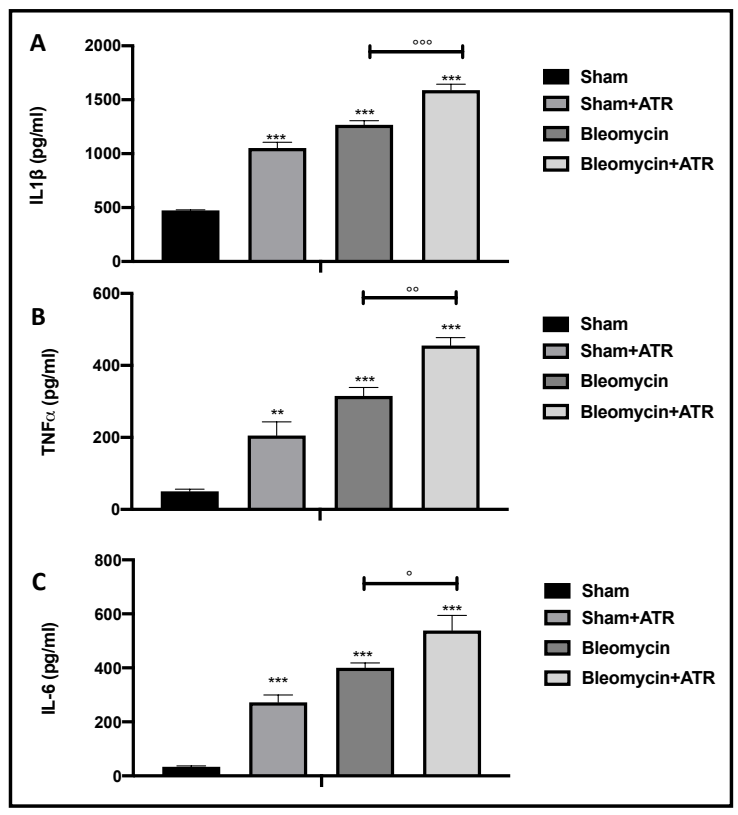

overproduction of free radicals resulted in an increase in lipid peroxidation, as reflected by the MDA levels (Fig. 7C).

The toxicity with bleomycin is initiated by direct oxidative damage, which then leads to subsequent general inflammation mediated by the generation of both intracellular and extracellular ROS. In particular, we found a significant increase in $\mathrm{H}_{2} \mathrm{O}_{2}$ in the plasma (Fig. 8A) as well as ROS (Fig. 8B) and RNS (Fig. 8C) species in the group subjected to ATR or BLM and even more so in the group subjected to both. 
Fig. 6. Exposure to ATR alters the physiological anti-oxidant system. Bleomycin instillation and/or ATR exposure induces significant perturbance to SOD (A), CAT (B) and GSH (C) activity. Data are expressed as the mean \pm SEM of $n=5$ mice/group. ${ }^{*} \mathrm{p}<0.05$ vs. Sham; ${ }^{* * *} \mathrm{p}<0.001$ vs. Sham; ${ }^{\circ} \mathrm{p}<0.05$ Bleomycin+ATR vs. Bleomycin; ${ }^{\circ} \mathrm{p}<0.01$ Bleomycin+ATR vs. Bleomycin; ${ }^{\circ \circ} \mathrm{p}<0.001$ Bleomycin+ATR vs. Bleomycin.
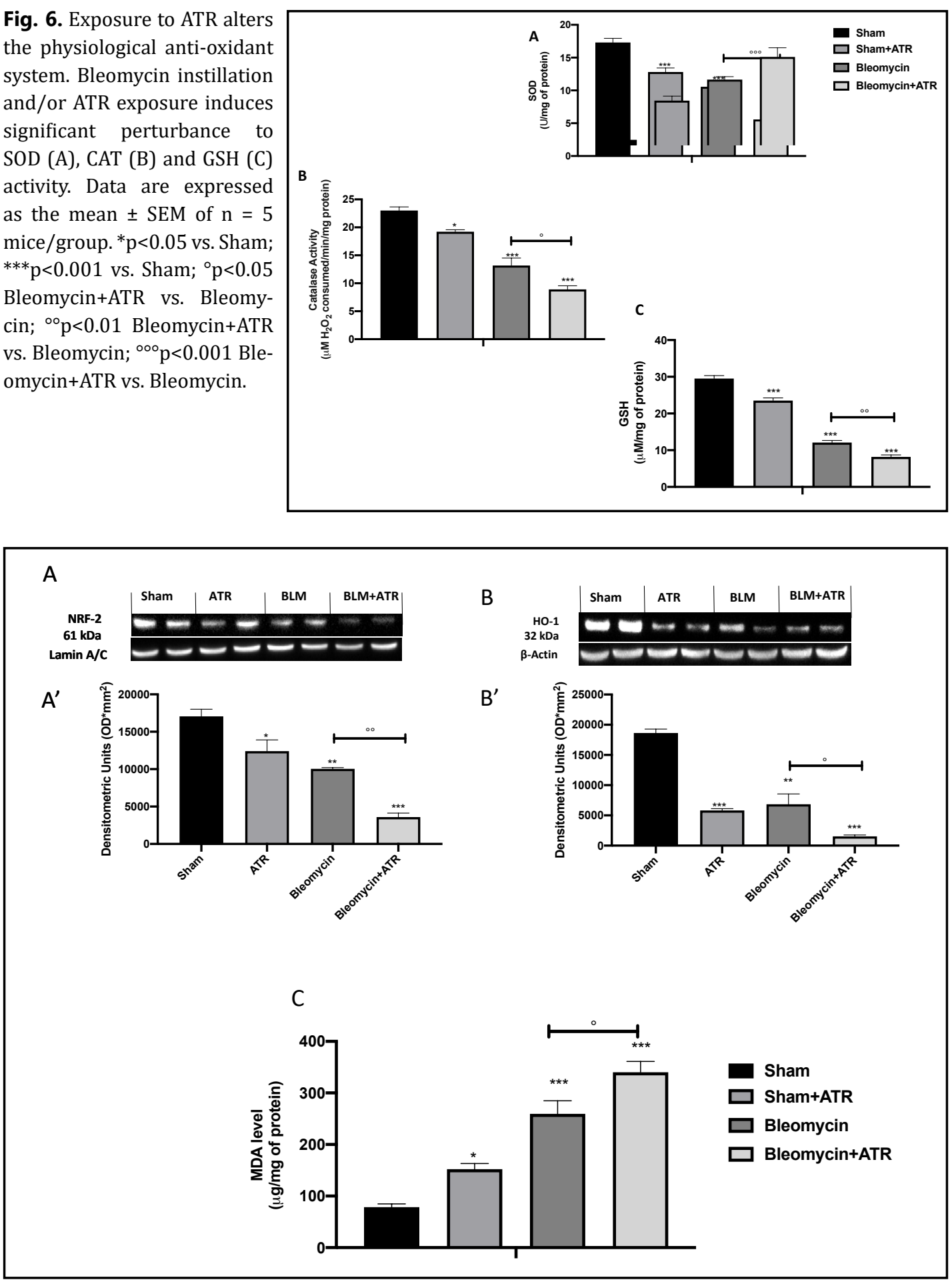

Fig. 7. Exposure to ATR decreases Nrf-2-HO-1 expression and increases lipid peroxidation in lung. Western blot analysis demonstrated that Nrf2 (A) and HO-1 (B) expressions were significantly reduced after bleomycin or ATR exposure. Additionally, an even more marked reduction was observed in the group subjected to both molecules. Protein lysates were also incubated with a $\beta$-actin or laminin antibody in order to verify that all samples had been loaded in uniform quantities. Densitometric representation of Nrf2 (A') and HO-1 (B') expressions. The same trend was found by investigating lipid peroxidation by MDA (C). Data are expressed as the mean \pm SEM of $n=5$ mice/group. ${ }^{*} \mathrm{p}<0.05$ vs. Sham; ${ }^{* *} \mathrm{p}<0.01$ vs. Sham; ${ }^{* * *} \mathrm{p}<0.001 \mathrm{vs.} \mathrm{Sham;}{ }^{\circ} \mathrm{p}<0.05$ Bleomycin+ATR vs. Bleomycin; ${ }^{\circ} \mathrm{p}<0.01$ Bleomycin+ATR vs. Bleomycin. 
Fig. 8. Exposure to ATR induces general oxidative stress state. Using the ELISA kit in the plasma, we found that bleomycin and/or ATR exposure induces significant general oxidative/nitrosative stress, in particular in $\mathrm{H}_{2} \mathrm{O}_{2}$ (A) ROS, and (B) and RNS (C). Data are expressed as the mean \pm SEM of $\mathrm{n}=5$ mice/group. ${ }^{*} \mathrm{p}<0.05$ vs. Sham; ${ }^{* *} \mathrm{p}<0.01$ vs. Sham; ${ }^{* * *} \mathrm{p}<0.001$ vs. Sham; ${ }^{\circ} \mathrm{p}<0.05$ Bleomycin+ ATR vs. Bleomycin; ${ }^{\circ} \mathrm{p}<0.01$ Bleomycin+ATR vs. Bleomycin.

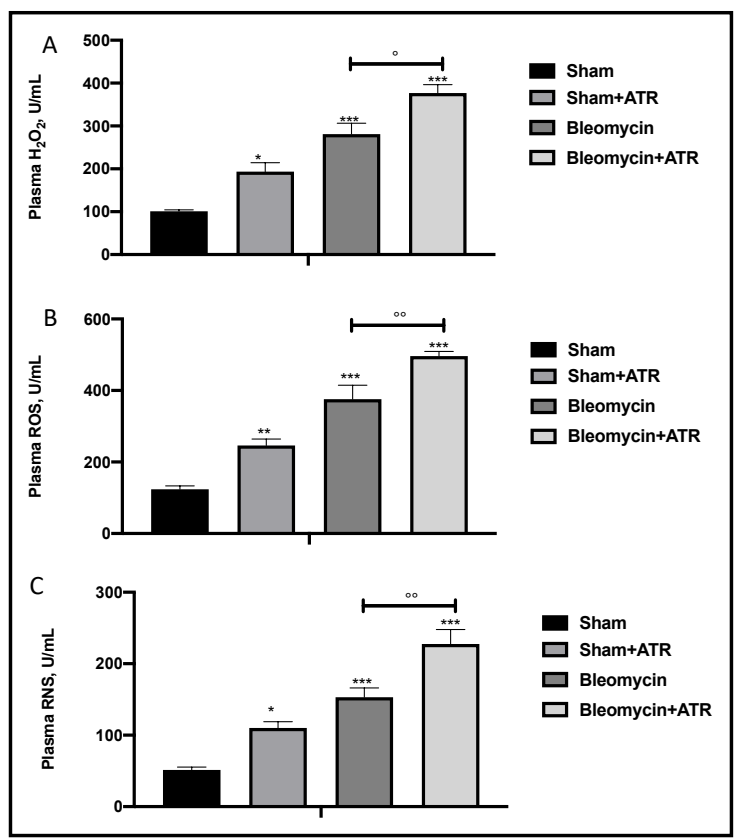

ATR exposure induces motor and non motor alterations

Some studies have demonstrated that behavioral comorbidities are probable in patients suffering from pulmonary pathologies [113]. On the other hand, to date, the knowledge about the effect of ATR and behavioral alterations remains poor and limited [65, 114]. For this reason, to investigate the relationship between lung inflammation and brain alteration, we analyzed the motor activity 1 day prior and 14 days after exposure to ATR, BLM or both. The data at time point 0 are not shown, as no significant differences between the different groups were observed. The pole test was used to assess bradykinesia [115]. Total time (Fig. 9A) and time to turn (Fig. 9B) did not undergo substantial changes following injections with bleomycin; however, they showed a significant increase in the groups exposed to ATR, suggesting a substantial augmentation of bradykinesia. In addition, using the rotarod test (Fig. 9C) and catalepsy test (Fig. 9D), we evaluated the motor function and cataleptic symptoms.

After 14 days, the group subjected to only injection with bleomycin showed minor, nonsignificant changes; however, in the group receiving ATR with or without bleomycin, the mice showed a significant reduction in motor activity and an increase in catalepsy.

Using different, well-recognized behavioral tests, we analyzed the degree of anxiety and locomotor function of mice with lung problems. Using the EPM test, we noted that mice exposed to ATR with or without BLM spent less time in open arms than control mice; however, BLM alone did not modify the time spent in open arms (Fig. 10A). As expected, the number of crossings was significantly reduced in the group exposed to ATR with or without BLM (Fig. 10B). This anxiety condition was also observed in mice exposed to ATR via the use of the OFT. In fact, mice exposed to ATR showed an increase in the tendency to stay outside the field near the wall when compared to the sham group. Moreover, in this case, BLM alone showed no significant alteration (Fig. 10C).

Furthermore, spatial learning and memory were assessed using a Barnes Maze. We observed an increase in escape latency (Fig. 10D) and in the average number of errors (Fig. $10 \mathrm{E}$ ) in the mice in the mice exposed to ATR with or without BLM when compared to the sham group. On the other hand, the group that received BLM alone showed similar behavior to that of the sham group. 
Fig. 9. Exposure to ATR induces motor impairment. After 14 days, mice exposed to ATR with or without bleomycin exhibited significant motor dysfunction as indicated by an increase in total time (A) and time to turn (B) and by a decrease in time spent on the rotarod (C). Moreover, catalepsy (D) indicated that ATR exposure but not bleomycin instillation induced significantly motor impairment. Data are expressed as the mean \pm SEM of $\mathrm{n}=5$ mice/group; $\mathrm{p}<0.001$ vs. Sham; ${ }^{\circ} \mathrm{p}<0.05$ Bleomycin+ATR vs. Bleomycin; ${ }^{\circ} \mathrm{p}<0.01$ Bleomycin+ ATR vs. Bleomycin.
$A$

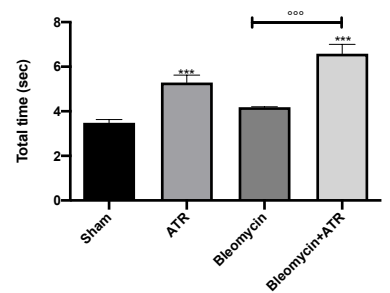

C

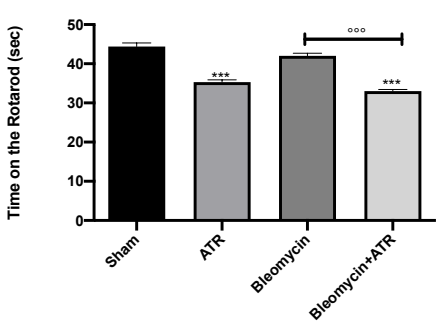

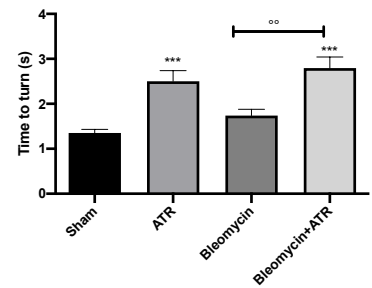

D

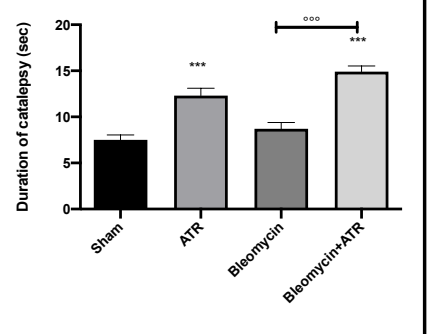

A

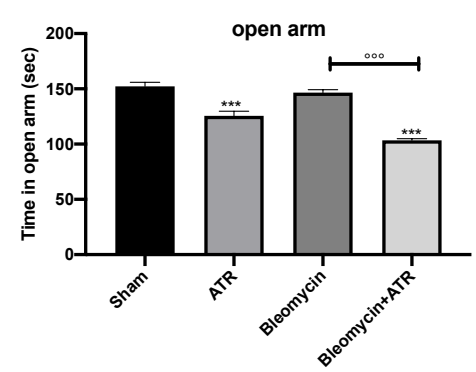

C

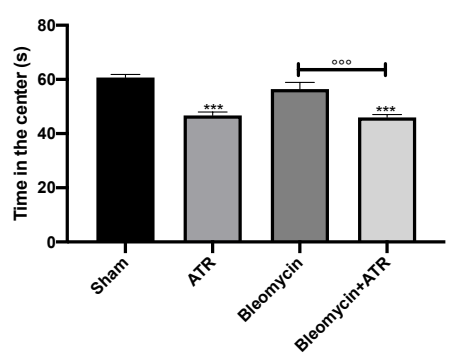

B

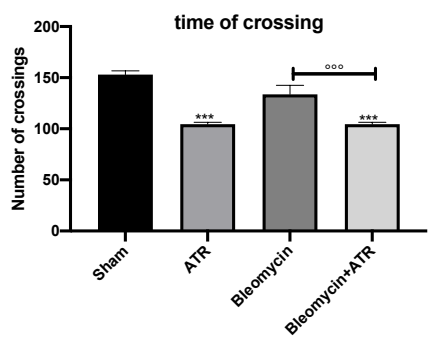

E
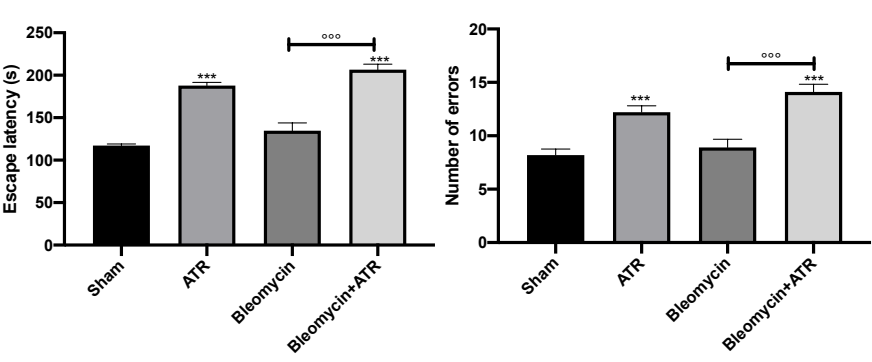

Fig. 10. Exposure to ATR induces behavioral alterations. The EPM test showed that mice exposed to ATR with or without BLM spent less time in open arms (A) and presented a reduced number of crossing (B) compared to that of the sham group. Additionally, using OFT, we observed that mice exposed to ATR tended to stay outside the field near the wall (C). Moreover, using a Barnes Maze, we noted an increase in escape latency (D) and in the average number of errors (E) in the mice exposed to ATR with or without BLM. The group that had received BLM alone showed a similar behavior to that of the sham group. ${ }^{* * *} \mathrm{p}<0.001 \mathrm{vs.}$ Sham; ${ }^{\circ \circ} \mathrm{p}<0.01$ Bleomycin+ATR vs. Bleomycin. 


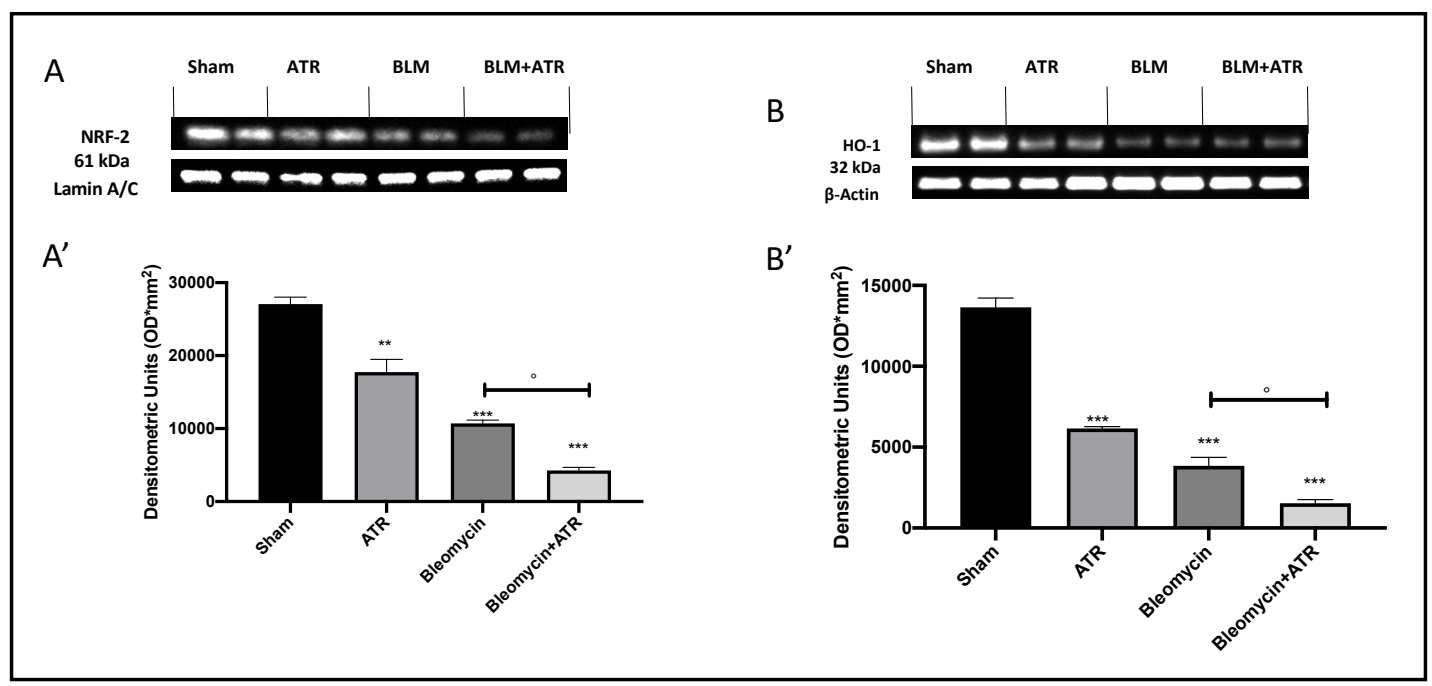

Fig. 11. Exposure to ATR decreases Nrf-2-HO-1 expression also in brain. Western blot analysis of brain tissue demonstrated that Nrf2 (A) and HO-1 (B) expressions were significantly reduced after bleomycin or ATR exposure. Additionally, an even more marked reduction was observed in the group subjected to both molecules. Protein lysates were also incubated with a $\beta$-actin or laminin antibody in order to verify that all samples had been loaded in uniform quantities. Densitometric representation of Nrf2 ( $A^{\prime}$ ) and HO-1 (B') expressions. Data are expressed as the mean \pm SEM of $n=5$ mice/group. ${ }^{*} p<0.05$ vs. Sham; ${ }^{* *} p<0.01$ vs. Sham; ${ }^{* * *} \mathrm{p}<0.001$ vs. Sham; ${ }^{\circ} \mathrm{p}<0.05$ Bleomycin+ATR vs. Bleomycin; ${ }^{\circ} \mathrm{p}<0.01$ Bleomycin+ATR vs. Bleomycin.

\section{ATR exposure induce Nrf-2 imbalance in brain}

To better understand if the behavioral alterations were related to oxidative stress we investigated the expression of Nrf-2 (Fig. 11A, A') as well as HO-1 (Fig. 11B, B') also in whole brain. We found that both markers were significantly decreased following exposure with ATR or bleomycin, and that this decrease was even more marked following exposure to both molecules.

\section{Discussion}

ATR is a herbicide commonly used for the control of broadleaf weeds. It is a man-made compound that does not exist naturally and is widely used on corn crops in the United States and Europe. The United States Environmental Protection Agency (EPA) has designated ATR as a restricted-use pesticide (RUP), meaning that only licensed herbicide users can purchase or use it due to its persistence in water and its various adverse health effects on humans. The maximum contamination level (MCL) for ATR is set at $3 \mathrm{ppb}(0.003 \mathrm{~g} / \mathrm{L})$ by EPA regulations [116]. Unlike the United States, Europe has stricter regulations on the use of ATR. A pesticides directive issued by the European Union (EU) in 1991 restricted the use of chemicals that were accused of causing harm to human health, groundwater, or the atmosphere [117]. Significant quantities of ATR that are not absorbed by plants will end up in the environment. ATR is only weakly adsorbed by soil particles after application and, thus, mainly leaves the field via runoff water. Rainfall washes large quantities of ATR out of the soil and into nearby areas, such as streams, reservoirs, and other waterways. Moreover, after it is added to the soil, small quantities of ATR may reach the air [118]. Humans are mainly exposed to ATR by the intake of tainted drinking water. However, inhalation exposure may occur during application on rare occasions. ATR's negative effects are still being studied [119]. In humans, increased risk of intrauterine growth retardation, decreased semen content, and spontaneous abortions were observed in many peer-reviewed studies, as were demasculinization and hermaphrodism in frogs [120-124]. 


\section{Cellular Physiology Cell Physiol Biochem 2021;55:704-725 \\ \begin{tabular}{ll|l} 
and Biochemistry & Published online: 18 November 2021 & $\begin{array}{l}\text { C } 2021 \text { The Author(s). Published by } \\
\text { Cell Physiol Biochem Press GmbH\&Co. KG }\end{array}$
\end{tabular} \\ D'Amico et al.: Atrazine Worsen Pulmonary Fibrosis}

IPF is a serious health issue that affects nearly 200,000 people in the United States and more than 5 million people globally. The disease has a $50 \%$ death rate in the first three years after diagnosis, although the prognosis is unpredictable [125].

Considering how many people suffer of IPF and considering that ATR is release in the atmosphere during production or application, is mandatory to investigate what happen when people are exposed to both.

Using an experimental model of PF induced by bleomycin, we analyzed for the first time the effects of ATR exposure on the inflammatory, oxidative and fibrotic parameters. Bleomycin-induced fibrosis is a well-established experimental model that reproduces the physiopathology of human disease, which is characterized by lung inflammation and loss of the original architecture of the lung due to excessive and disorganized expression, deposition of collagen and extracellular matrix and inflammation.

It has thus been demonstrated that ATR can induce oxidative stress conditions following oxidative imbalance induced by the impairment of physiological antioxidant defenses, and previous studies have reported the effect of ATR on the lungs. Here, for the time, we determined whether ATR exposure may contribute to the worsening of PF $[17,20,64,126$ 128].

$\mathrm{PF}$ is characterized by progressive lesions of the pulmonary parenchyma, inflammatory infiltrate, fibrosis in the interstitial space and cellular recruitment $[129,130]$. Here, we first evaluated the lung damage and the cells recruited in the BAL. Our results showed FA exposure in fibrosis, and we noted that ATR not only causes an alteration in the lung tissue as well as significant cell recruitment, but it is also able to further worsen tissue alterations and cellular recruitment induced by bleomycin. In addition, mediators released by cells contribute to the proliferation of resident fibroblasts as well as their differentiation into myofibroblasts (activated fibroblasts secreting large amounts of collagen) [131]. In our study, we additionally demonstrated for the first time by Masson trichrome and immunohistochemical localization of $\alpha$-SMA expression that air exposure to ATR induces a significant promotion of fibrosis and a further increase in collagen deposition and $\alpha$-SMA expression when administrated simultaneously with bleomycin. Different cytokines play crucial roles in PF progression $[132,133]$. For this reason, we determined whether ATR is involved in the cellular secretion of IL-1 $\beta$, IL- 6 and TNF- $\alpha$. Our results show the IL-1 $\beta$, IL- 6 and TNF- $\alpha$ secretions in the group subjected to bleomycin and demonstrate that ATR was significantly high in the groups that had received single treatment.

The respiratory system is one of the body's main connections with the outside world, and it must deal with and detoxify antigens and particles inhaled. It must regulate and express inflammatory pathways in such a way that the respiratory system's primary functions are preserved while still providing protection against invasion by foreign infective agents or antigens [134-137]. As described above, ATR exposure and PF have in common an increase in ROS and RNS as well as alterations in Nrf2 pathways, SOD, CAT and GSH $[49,138]$.

In our work, we found that following exposure to ATR, bleomycin or both via inhalation, cells undergo a decrease in activity of physiological antioxidants. Moreover, in these parameters, ATR exposure together with bleomycin injection significantly worsens the whole situation.

When a condition of very strong oxidative stress is established, it is unlikely to remain compartmentalized in a single organ; rather, it often affects the whole body. Many oxidative stress measurements may be collected using minimally invasive methods, for example, in blood, making them reasonably simple to use in both animal and human studies. In our work, we noted that in blood, the onset of a generalized increase in oxidative and nitrosative stress that significantly worsened when ATR was inhaled by mice exposed to bleomycin. There is a link between lung difficulties and brain comorbidities, according to many research. This is likely attributable to 1) decreased treatment compliance in depressed patients; 2) a worsened sense of dyspnea in depressed and anxious patients, which may result in greater hospital admissions; and 3) a sad and/or anxious patient's ability to cope with a chronic disease. On the other hand, cognitive problems are associated with worsening of the disease 


\section{Cellular Physiology Cell Physiol Biochem 2021;55:704-725

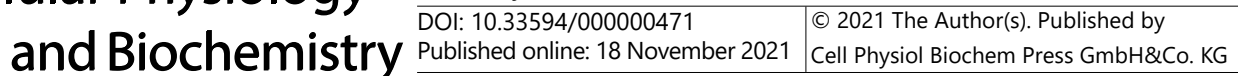 \\ D'Amico et al.: Atrazine Worsen Pulmonary Fibrosis}

progression, which leads to an infinity loop until death [139-149]. Considering the severity of the worsened symptoms, the treatment for such brain comorbidities requires further investigations [150]. In our study, we observed a significant alteration in motor and nonmotor symptoms in mice exposed to both ATR and bleomycin but not in mice exposed to only bleomycin.

Despite the fact that different research have focused on Nrf-2's neuroprotective properties against neurodegenerative stimuli/damage, the physiological roles Nrf2 plays in the brain have not been extensively characterized. While a decrease of Nrf2 seems not to lead immediately to behavioral disorders, we assume that the alteration of Nrf2 may increase the risk for these diseases in combination with other genetic or environmental factors.

Taken together, our data represent an addition to the complex information on ATRinduced pulmonary toxicity. In particular, in this study, we aimed to demonstrate that not only is atrazine able to induce alterations to lung parenchyma, fibrosis, oxidative stress, inflammation and behavioral alterations, but it can also worsen the situation that arises following the injection of bleomycin. This could also represent the first step in recognizing that this substance as a problematic air pollutant and not only a water and/or soil pollutant.

\section{Acknowledgements}

\section{Author Contributions}

Conceptualization, M.C. and T.G.; formal analysis, A.F.P. and R.S..; investigation, R.D.; methodology, E.G. and R.C.; project administration, S.C. and R.D.P.; supervision, F.M. and R.D.P.; validation, R.F. and D.I.; writing-review and editing, R.F. and M.C.

\section{Funding Sources}

This research was supported in part by Ministero dell'Istruzione, dell'Università e della Ricerca (MIUR), PRIN 2017 (Prot. 2017MLC3NF).

\section{Disclosure Statement}

The authors have no conflicts of interest to declare.

\section{References}

1 Faner R, Rojas M, Macnee W, Agusti A: Abnormal lung aging in chronic obstructive pulmonary disease and idiopathic pulmonary fibrosis. Am J Respir Crit Care Med 2012;186:306-313.

2 Jones DP: Extracellular redox state: refining the definition of oxidative stress in aging. Rejuvenation Res 2006;9:169-181.

3 Sanchez-Valle V, Chavez-Tapia NC, Uribe M, Mendez-Sanchez N: Role of oxidative stress and molecular changes in liver fibrosis: a review. Curr Med Chem 2012;19:4850-4860.

4 Yu G, Tzouvelekis A, Wang R, Herazo-Maya JD, Ibarra GH, Srivastava A, de Castro JPW, Deluliis G, Ahangari F, Woolard T, Aurelien N, Arrojo EDR, Gan Y, Graham M, Liu X, Homer RJ, Scanlan TS, Mannam P, Lee PJ, Herzog EL, et al.: Thyroid hormone inhibits lung fibrosis in mice by improving epithelial mitochondrial function. Nat Med 2018;24:39-49.

5 Behr J, Degenkolb B, Maier K, Braun B, Beinert T, Krombach F, Vogelmeier C, Fruhmann G: Increased oxidation of extracellular glutathione by bronchoalveolar inflammatory cells in diffuse fibrosing alveolitis. Eur Respir J 1995;8:1286-1292.

6 Behr J, Degenkolb B, Krombach F, Vogelmeier C: Intracellular glutathione and bronchoalveolar cells in fibrosing alveolitis: effects of N-acetylcysteine. Eur Respir J 2002;19:906-911.

7 Cantin AM, Hubbard RC, Crystal RG: Glutathione deficiency in the epithelial lining fluid of the lower respiratory tract in idiopathic pulmonary fibrosis. Am Rev Respir Dis 1989;139:370-372. 


\section{Cellular Physiology Cell Physiol Biochem 2021;55:704-725 \begin{tabular}{ll|l} 
and Biochemistry & DOl: 10.33594/000000471 & Published online: 18 November 2021 The Author(s). Published by \\
Cell Physiol Biochem Press GmbH\&Co. KG
\end{tabular}}

8 Borok Z, Buhl R, Grimes GJ, Bokser AD, Hubbard RC, Holroyd KJ, Roum JH, Czerski DB, Cantin AM, Crystal RG: Effect of glutathione aerosol on oxidant-antioxidant imbalance in idiopathic pulmonary fibrosis. Lancet 1991;338:215-216.

9 Tiitto L, Kaarteenaho-Wiik R, Sormunen R, Holmgren A, Paakko P, Soini Y, Kinnula VL: Expression of the thioredoxin system in interstitial lung disease. J Pathol 2003;201:363-370.

10 Lakari E, Paakko P, Pietarinen-Runtti P, Kinnula VL: Manganese superoxide dismutase and catalase are coordinately expressed in the alveolar region in chronic interstitial pneumonias and granulomatous diseases of the lung. Am J Respir Crit Care Med 2000;161:615-621.

11 Derghal A, Djelloul M, Trouslard J, Mounien L: An Emerging Role of micro-RNA in the Effect of the Endocrine Disruptors. Front Neurosci 2016;10:318.

12 Polyzos SA, Kountouras J, Deretzi G, Zavos C, Mantzoros CS: The emerging role of endocrine disruptors in pathogenesis of insulin resistance: a concept implicating nonalcoholic fatty liver disease. Curr Mol Med 2012;12:68-82.

13 Koch CA, Diamanti-Kandarakis E: Introduction to Endocrine Disrupting Chemicals--is it time to act? Rev Endocr Metab Disord 2015;16:269-270.

14 Dodson RE, Nishioka M, Standley LJ, Perovich LJ, Brody JG, Rudel RA: Endocrine disruptors and asthmaassociated chemicals in consumer products. Environ Health Perspect 2012;120:935-943.

15 Song XY, Li JN, Wu YP, Zhang B, Li BX: Atrazine Causes Autophagy- and Apoptosis-Related Neurodegenerative Effects in Dopaminergic Neurons in the Rat Nigrostriatal Dopaminergic System. Int J Mol Sci 2015;16:13490-13506.

16 Bhatti JS, Sidhu IP, Bhatti GK: Ameliorative action of melatonin on oxidative damage induced by atrazine toxicity in rat erythrocytes. Mol Cell Biochem 2011;353:139-149.

17 Zhao F, Li K, Zhao L, Liu J, Suo Q, Zhao J, Wang H, Zhao S: Effect of Nrf2 on rat ovarian tissues against atrazine-induced anti-oxidative response. Int J Clin Exp Pathol 2014;7:2780-2789.

18 Lin J, Xia J, Zhao HS, Hou R, Talukder M, Yu L, Guo JY, Li JL: Lycopene Triggers Nrf2-AMPK Cross Talk to Alleviate Atrazine-Induced Nephrotoxicity in Mice. J Agric Food Chem 2018;66:12385-12394.

19 Rezaie Agdam H, Razi M, Amniattalab A, Malekinejad H, Molavi M: Co-Administration of Vitamin E and Testosterone Attenuates The Atrazine-Induced Toxic Effects on Sperm Quality and Testes in Rats. Cell J 2017;19:292-305.

20 Liu W, Du Y, Liu J, Wang H, Sun D, Liang D, Zhao L, Shang J: Effects of atrazine on the oxidative damage of kidney in Wister rats. Int J Clin Exp Med 2014;7:3235-3243.

21 Gao S, Wang Z, Zhang C, Jia L, Zhang Y: Oral Exposure to Atrazine Induces Oxidative Stress and Calcium Homeostasis Disruption in Spleen of Mice. Oxid Med Cell Longev 2016;2016:7978219.

22 Droge W: Free radicals in the physiological control of cell function. Physiol Rev 2002;82:47-95.

23 Thannickal VJ, Fanburg BL: Reactive oxygen species in cell signaling. Am J Physiol Lung Cell Mol Physiol 2000;279:L1005-1028.

24 Chan KM, Kan YW: Nrf2 is essential for protection against acute pulmonary injury in mice. Proc Natl Acad Sci U S A 1999;96:12731-12736.

25 Cho HY, Jedlicka AE, Reddy SP, Kensler TW, Yamamoto M, Zhang LY, Kleeberger SR: Role of NRF2 in protection against hyperoxic lung injury in mice. Am J Respir Cell Mol Biol 2002;26:175-182.

26 Cho HY, Reddy SPM, Yamamoto M, Kleeberger SR: The transcription factor NRF2 protects against pulmonary fibrosis. FASEB J 2004;18:1258-1260.

27 Walters DM, Cho HY, Kleeberger SR: Oxidative stress and antioxidants in the pathogenesis of pulmonary fibrosis: A potential role for Nrf2. Antioxid Redox Signal 2008;10:321-332.

28 Kikuchi N, Ishii Y, Morishima Y, Yageta Y, Haraguchi N, Itoh K, Yamamoto M, Hizawa N: Nrf2 protects against pulmonary fibrosis by regulating the lung oxidant level and Th1/Th2 balance. Respir Res 2010;11:31.

29 Singh M, Kaur P, Sandhir R, Kiran R: Protective effects of vitamin E against atrazine-induced genotoxicity in rats. Mutat Res 2008;654:145-149.

30 Simpkins JW, Swenberg JA, Weiss N, Brusick D, Eldridge JC, Stevens JT, Handa RJ, Hovey RC, Plant TM, Pastoor TP, Breckenridge CB: Atrazine and Breast Cancer: A Framework Assessment of the Toxicological and Epidemiological Evidence. Toxicol Sci 2011;123:441-459.

31 Inoue-Choi M, Weyer PJ, Jones RR, Booth BJ, Cantor KP, Robien K, Ward MH: Atrazine in public water supplies and risk of ovarian cancer among postmenopausal women in the Iowa Women's Health Study. Occup Environ Med 2016;73:582-587. 


\section{Cellular Physiology Cell Physiol Biochem 2021;55:704-725 \begin{tabular}{ll|l} 
and Biol: 10.33594/000000471 & (c)21 The Author(s). Published by
\end{tabular} and Biochemistry Published online: 18 November 2021 Cell Physiol Biochem Press GmbH\&Co. KG \\ D'Amico et al.: Atrazine Worsen Pulmonary Fibrosis}

32 Hu K, Tian Y, Du Y, Huang L, Chen J, Li N, Liu W, Liang Z, Zhao L: Atrazine promotes RM1 prostate cancer cell proliferation by activating STAT3 signaling. Int J Oncol 2016;48:2166-2174.

33 Albanito L, Lappano R, Madeo A, Chimento A, Prossnitz ER, Cappello AR, Dolce V, Abonante S, Pezzi V, Maggiolini M: Effects of atrazine on estrogen receptor alpha- and G protein-coupled receptor 30-mediated signaling and proliferation in cancer cells and cancer-associated fibroblasts. Environ Health Perspect 2015;123:493-499.

34 Boffetta P, Adami HO, Berry SC, Mandel JS: Atrazine and cancer: a review of the epidemiologic evidence. Eur J Cancer Prev 2013;22:169-180.

35 Freeman LE, Rusiecki JA, Hoppin JA, Lubin JH, Koutros S, Andreotti G, Zahm SH, Hines CJ, Coble JB, Barone-Adesi F, Sloan J, Sandler DP, Blair A, Alavanja MC: Atrazine and cancer incidence among pesticide applicators in the agricultural health study (1994-2007). Environ Health Perspect 2011;119:1253-1259.

36 McElroy JA, Gangnon RE, Newcomb PA, Kanarek MS, Anderson HA, Brook JV, Trentham-Dietz A, Remington PL: Risk of breast cancer for women living in rural areas from adult exposure to atrazine from well water in Wisconsin. J Expo Sci Environ Epidemiol 2007;17:207-214.

37 Rusiecki JA, De Roos A, Lee WJ, Dosemeci M, Lubin JH, Hoppin JA, Blair A, Alavanja MC: Cancer incidence among pesticide applicators exposed to atrazine in the Agricultural Health Study. J Natl Cancer Inst 2004;96:1375-1382.

38 Hessel PA, Kalmes R, Smith TJ, Lau E, Mink PJ, Mandel J: A nested case-control study of prostate cancer and atrazine exposure. J Occup Environ Med 2004;46:379-385.

39 Van Leeuwen JA, Waltner-Toews D, Abernathy T, Smit B, Shoukri M: Associations between stomach cancer incidence and drinking water contamination with atrazine and nitrate in Ontario (Canada) agroecosystems, 1987-1991. Int J Epidemiol 1999;28:836-840.

40 Hoppin JA, Umbach DM, London SJ, Alavanja MC, Sandler DP: Chemical predictors of wheeze among farmer pesticide applicators in the Agricultural Health Study. Am J Respir Crit Care Med 2002;165:683-689.

41 Fusco R, Cordaro M, Genovese T, Impellizzeri D, Siracusa R, Gugliandolo E, Peritore AF, D’Amico R, Crupi R, Cuzzocrea S, Di Paola R: Adelmidrol: A New Promising Antioxidant and Anti-Inflammatory Therapeutic Tool in Pulmonary Fibrosis. Antioxidants (Basel) 2020;9:601.

42 Huai B, Ding J: Atractylenolide III attenuates bleomycin-induced experimental pulmonary fibrosis and oxidative stress in rat model via Nrf2/NQ01/HO-1 pathway activation. Immunopharmacol Immunotoxicol 2020;42:436-444.

43 Ahmad A, Alkharfy KM, Jan BL, Ahad A, Ansari MA, Al-Jenoobi FI, Raish M: Thymoquinone treatment modulates the Nrf2/HO-1 signaling pathway and abrogates the inflammatory response in an animal model of lung fibrosis. Exp Lung Res 2020;46:53-63.

44 Peng LY, An L, Sun NY, Ma Y, Zhang XW, Liu WH, Liu BL, Li P, Chen J: Salvia miltiorrhiza Restrains Reactive Oxygen Species-Associated Pulmonary Fibrosis via Targeting Nrf2-Nox4 Redox Balance. Am J Chin Med 2019;47:1113-1131.

45 Liu B, Rong Y, Sun D, Li W, Chen H, Cao B, Wang T: Costunolide inhibits pulmonary fibrosis via regulating NF-kB and TGF-beta1/Smad2/Nrf2-NOX4 signaling pathways. Biochem Biophys Res Commun 2019;510:329-333.

46 Zhang Z, Qu J, Zheng C, Zhang P, Zhou W, Cui W, Mo X, Li L, Xu L, Gao J: Nrf2 antioxidant pathway suppresses Numb-mediated epithelial-mesenchymal transition during pulmonary fibrosis. Cell Death Dis 2018;9:83.

47 Li YJ, Shimizu T, Shinkai Y, Hirata Y, Inagaki H, Takeda K, Azuma A, Yamamoto M, Kawada T: Nrf2 Regulates the Risk of a Diesel Exhaust Inhalation-Induced Immune Response during Bleomycin Lung Injury and Fibrosis in Mice. Int J Mol Sci 2017;18:649.

48 Zhou W, Mo X, Cui W, Zhang Z, Li D, Li L, Xu L, Yao H, Gao J: Nrf2 inhibits epithelial-mesenchymal transition by suppressing snail expression during pulmonary fibrosis. Sci Rep 2016;6:38646.

49 Cho HY, Reddy SP, Kleeberger SR: Nrf2 defends the lung from oxidative stress. Antioxid Redox Signal 2006;8:76-87.

50 Cho HY, Reddy SP, Yamamoto M, Kleeberger SR: The transcription factor NRF2 protects against pulmonary fibrosis. FASEB J 2004;18:1258-1260.

51 Lee AL, Goldstein RS, Brooks D: Chronic Pain in People With Chronic Obstructive Pulmonary Disease: Prevalence, Clinical and Psychological Implications. Chronic Obstr Pulm Dis 2017;4:194-203.

52 Maurer J: Anxiety and depression in COPD: Current understanding, unanswered questions, and research needs. Rev Port Pneumol 2009;15:740-742. 


\section{Cellular Physiology Cell Physiol Biochem 2021;55:704-725 \begin{tabular}{ll|l|l|l}
\hline DOl: 10.33594/000000471 & ( 2021 The Author(s). Published by \\
\hline
\end{tabular} and Biochemistry Published online: 18 November 2021 Cell Physiol Biochem Press GmbH\&Co. KG \\ D'Amico et al.: Atrazine Worsen Pulmonary Fibrosis}

53 Maurer J, Rebbapragada V, Borson S, Goldstein R, Kunik ME, Yohannes AM, Hanania NA, Anxiety AWPo, Depression in C: Anxiety and depression in COPD: current understanding, unanswered questions, and research needs. Chest 2008;134:43S-56S.

54 Wen XH, Li Y, Han D, Sun L, Ren PX, Ren D: The relationship between cognitive function and arterial partial pressure 02 in patients with COPD: A meta-analysis. Medicine (Baltimore) 2018;97:e9599.

55 Yohannes AM, Chen W, Moga AM, Leroi I, Connolly MJ: Cognitive Impairment in Chronic Obstructive Pulmonary Disease and Chronic Heart Failure: A Systematic Review and Meta-analysis of Observational Studies. J Am Med Dir Assoc 2017;18:451 e451-451 e411.

56 Yohannes AM, Willgoss TG, Baldwin RC, Connolly MJ: Depression and anxiety in chronic heart failure and chronic obstructive pulmonary disease: prevalence, relevance, clinical implications and management principles. Int J Geriatr Psychiatry 2010;25:1209-1221.

57 Ranzini L, Schiavi M, Pierobon A, Granata N, Giardini A: From Mild Cognitive Impairment (MCI) to Dementia in Chronic Obstructive Pulmonary Disease. Implications for Clinical Practice and Disease Management: A Mini-Review. Front Psychol 2020;11:337.

58 Baird C, Lovell J, Johnson M, Shiell K, Ibrahim JE: The impact of cognitive impairment on self-management in chronic obstructive pulmonary disease: A systematic review. Respir Med 2017;129:130-139.

59 Cleutjens FA, Janssen DJ, Ponds RW, Dijkstra JB, Wouters EF: COgnitive-pulmonary disease. Biomed Res Int 2014;2014:697825.

60 Conte E, Fagone E, Gili E, Fruciano M, Iemmolo M, Pistorio MP, Impellizzeri D, Cordaro M, Cuzzocrea S, Vancheri C: Preventive and therapeutic effects of thymosin beta $4 \mathrm{~N}$-terminal fragment Ac-SDKP in the bleomycin model of pulmonary fibrosis. Oncotarget 2016;7:33841-33854.

61 Schramm CM, Puddington L, Wu C, Guernsey L, Gharaee-Kermani M, Phan SH, Thrall RS: Chronic inhaled ovalbumin exposure induces antigen-dependent but not antigen-specific inhalational tolerance in a murine model of allergic airway disease. Am J Pathol 2004;164:295-304.

62 Vaughan RP, Szewczyk MT, Jr., Lanosa MJ, Desesa CR, Gianutsos G, Morris JB: Adenosine sensory transduction pathways contribute to activation of the sensory irritation response to inspired irritant vapors. Toxicol Sci 2006;93:411-421.

63 Ramona D’Amico FM, Roberta Fusco, Alessio Filippo Peritore, Tiziana Genovese, Daniela Impellizzeri, Rosalia Crupi, Livia Interdonato, Andrea Maria Sforza, Enrico Gugliandolo, Rosalba Siracusa, Salvatore Cuzzocre, Marika Cordaro, Rosanna Di Paola: Exposure to Atrazine Induces Lung Inflammation through Nrf2-HO1 and Beclin 1/LC3 Pathways. Cell Physiol Biochem 2021;55:413-427.

64 Zhang X, Wang M, Gao S, Ren R, Zheng J, Zhang Y: Atrazine-induced apoptosis of splenocytes in BALB/C mice. BMC Med 2011;9:117.

65 Li J, Li X, Bi H, Ma K, Li B: Developmental Exposure to Atrazine Impairs Spatial Memory and Downregulates the Hippocampal D1 Dopamine Receptor and cAMP-Dependent Signaling Pathway in Rats. Int J Mol Sci 2018;19:2241.

66 Schramm CM, Puddington L, Wu C, Guernsey L, Gharaee-Kermani M, Phan SH, Thrall RS: Chronic inhaled ovalbumin exposure induces antigen-dependent but not antigen-specific inhalational tolerance in a murine model of allergic airway disease. Am J Pathol 2004;164:295-304.

67 Filipov NM, Pinchuk LM, Boyd BL, Crittenden PL: Immunotoxic effects of short-term atrazine exposure in young male C57BL/6 mice. Toxicol Sci 2005;86:324-332.

68 Lin Z, Dodd CA, Filipov NM: Short-term atrazine exposure causes behavioral deficits and disrupts monoaminergic systems in male C57BL/6 mice. Neurotoxicol Teratol 2013;39:26-35.

69 Coban A, Filipov NM: Dopaminergic toxicity associated with oral exposure to the herbicide atrazine in juvenile male C57BL/6 mice. J Neurochem 2007;100:1177-1187.

70 Di Paola R, Impellizzeri D, Fusco R, Cordaro M, Siracusa R, Crupi R, Esposito E, Cuzzocrea S: Ultramicronized palmitoylethanolamide (PEA-um((R))) in the treatment of idiopathic pulmonary fibrosis. Pharmacol Res 2016;111:405-412.

71 Impellizzeri D, Talero E, Siracusa R, Alcaide A, Cordaro M, Maria Zubelia J, Bruschetta G, Crupi R, Esposito E, Cuzzocrea S, Motilva V: Protective effect of polyphenols in an inflammatory process associated with experimental pulmonary fibrosis in mice. Br J Nutr 2015;114:853-865.

72 Manitsopoulos N, Nikitopoulou I, Maniatis NA, Magkou C, Kotanidou A, Orfanos SE: Highly Selective Endothelin-1 Receptor A Inhibition Prevents Bleomycin-Induced Pulmonary Inflammation and Fibrosis in Mice. Respiration 2018;95:122-136. 


\section{Cellular Physiology Cell Physiol Biochem 2021;55:704-725 \begin{tabular}{l|l|l} 
and Biol: 10.33594/000000471 & D 2021 The Author(s). Published by
\end{tabular} and BIOChemistry Published online: 18 November 2021 Cell Physiol Biochem Press GmbH\&Co. KG \\ D'Amico et al.: Atrazine Worsen Pulmonary Fibrosis}

73 Kato S, Inui N, Hakamata A, Suzuki Y, Enomoto N, Fujisawa T, Nakamura Y, Watanabe H, Suda T: Changes in pulmonary endothelial cell properties during bleomycin-induced pulmonary fibrosis. Respir Res 2018;19:127.

74 Cordaro M, Paterniti I, Siracusa R, Impellizzeri D, Esposito E, Cuzzocrea S: KU0063794, a Dual mTORC1 and mTORC2 Inhibitor, Reduces Neural Tissue Damage and Locomotor Impairment After Spinal Cord Injury in Mice. Mol Neurobiol 2017;54:2415-2427.

75 Siracusa R, Impellizzeri D, Cordaro M, Crupi R, Esposito E, Petrosino S, Cuzzocrea S: Anti-Inflammatory and Neuroprotective Effects of Co-UltraPEALut in a Mouse Model of Vascular Dementia. Front Neurol 2017;8:233.

76 Fusco R, D’Amico R, Cordaro M, Gugliandolo E, Siracusa R, Peritore AF, Crupi R, Impellizzeri D, Cuzzocrea S, Di Paola R: Absence of formyl peptide receptor 1 causes endometriotic lesion regression in a mouse model of surgically-induced endometriosis. Oncotarget 2018;9:31355-31366.

77 Cordaro M, Impellizzeri D, Gugliandolo E, Siracusa R, Crupi R, Esposito E, Cuzzocrea S: Adelmidrol, a Palmitoylethanolamide Analogue, as a New Pharmacological Treatment for the Management of Inflammatory Bowel Disease. Mol Pharmacol 2016;90:549-561.

78 Campolo M, Esposito E, Ahmad A, Di Paola R, Paterniti I, Cordaro M, Bruschetta G, Wallace JL, Cuzzocrea S: Hydrogen sulfide-releasing cyclooxygenase inhibitor ATB-346 enhances motor function and reduces cortical lesion volume following traumatic brain injury in mice. J Neuroinflammation 2014;11:196.

79 Fusco R, Siracusa R, D’Amico R, Peritore AF, Cordaro M, Gugliandolo E, Crupi R, Impellizzeri D, Cuzzocrea S, Di Paola R: Melatonin Plus Folic Acid Treatment Ameliorates Reserpine-Induced Fibromyalgia: An Evaluation of Pain, Oxidative Stress, and Inflammation. Antioxidants (Basel) 2019;8:628.

80 Di Paola R, Fusco R, Gugliandolo E, D’Amico R, Campolo M, Latteri S, Carughi A, Mandalari G, Cuzzocrea S: The Antioxidant Activity of Pistachios Reduces Cardiac Tissue Injury of Acute Ischemia/Reperfusion (I/R) in Diabetic Streptozotocin (STZ)-Induced Hyperglycaemic Rats. Front Pharmacol 2018;9:51.

81 Paterniti I, Impellizzeri D, Cordaro M, Siracusa R, Bisignano C, Gugliandolo E, Carughi A, Esposito E, Mandalari G, Cuzzocrea S: The Anti-Inflammatory and Antioxidant Potential of Pistachios (Pistacia vera L.) In Vitro and In Vivo. Nutrients 2017;9:915.

82 D’Amico R, Fusco R, Gugliandolo E, Cordaro M, Siracusa R, Impellizzeri D, Peritore AF, Crupi R, Cuzzocrea S, Di Paola R: Effects of a new compound containing Palmitoylethanolamide and Baicalein in myocardial ischaemia/reperfusion injury in vivo. Phytomedicine 2019;54:27-42.

83 Wang S, Yang Y, Luo D, Wu D, Liu H, Li M, Sun Q, Jia L: Lung inflammation induced by exposure to Bisphenol-A is associated with mTOR-mediated autophagy in adolescent mice. Chemosphere 2020;248:126035.

84 Fusco R, Siracusa R, D’Amico R, Cordaro M, Genovese T, Gugliandolo E, Peritore AF, Crupi R, Di Paola R, Cuzzocrea S, Impellizzeri D: Mucosa-Associated Lymphoid Tissue Lymphoma Translocation 1 Inhibitor as a Novel Therapeutic Tool for Lung Injury. Int J Mol Sci 2020;21:7761.

85 Conte E, Genovese T, Gili E, Esposito E, Iemmolo M, Fruciano M, Fagone E, Pistorio MP, Crimi N, Cuzzocrea S, Vancheri C: Thymosin beta4 protects C57BL/6 mice from bleomycin-induced damage in the lung. Eur J Clin Invest 2013;43:309-315.

86 Ashcroft T, Simpson JM, Timbrell V: Simple method of estimating severity of pulmonary fibrosis on a numerical scale. J Clin Pathol 1988;41:467-470.

87 Fusco R, Siracusa R, Peritore AF, Gugliandolo E, Genovese T, D’Amico R, Cordaro M, Crupi R, Mandalari G, Impellizzeri D, Cuzzocrea S, Di Paola R: The Role of Cashew (Anacardium occidentale L.) Nuts on an Experimental Model of Painful Degenerative Joint Disease. Antioxidants (Basel) 2020;9:511.

88 Peritore AF, Siracusa R, Fusco R, Gugliandolo E, D’Amico R, Cordaro M, Crupi R, Genovese T, Impellizzeri D, Cuzzocrea S, Di Paola R: Ultramicronized Palmitoylethanolamide and Paracetamol, a New Association to Relieve Hyperalgesia and Pain in a Sciatic Nerve Injury Model in Rat. Int J Mol Sci 2020;21:3509.

89 Fusco R, Cordaro M, Siracusa R, D’Amico R, Genovese T, Gugliandolo E, Peritore AF, Crupi R, Impellizzeri D, Cuzzocrea S, Di Paola R: Biochemical Evaluation of the Antioxidant Effects of Hydroxytyrosol on Pancreatitis-Associated Gut Injury. Antioxidants (Basel) 2020;9:781.

90 Sawant S, Gokulan R, Dongre H, Vaidya M, Chaukar D, Prabhash K, Ingle A, Joshi S, Dange P, Joshi S, Singh AK, Makani V, Sharma S, Jeyaram A, Kane S, D’Cruz A: Prognostic role of Oct4, CD44 and c-Myc in radio-chemoresistant oral cancer patients and their tumourigenic potential in immunodeficient mice. Clin Oral Investig 2016;20:43-56. 


\section{Cellular Physiology Cell Physiol Biochem 2021;55:704-725 \begin{tabular}{ll|l|l|l}
\hline DOI: 10.33594/000000471 & (021 The Author(s). Published by \\
\hline
\end{tabular} and Biochemistry Published online: 18 November 2021 Cell Physiol Biochem Press GmbH\&Co. KG

91 Cuzzocrea S, Mazzon E, Esposito E, Muia C, Abdelrahman M, Di Paola R, Crisafulli C, Bramanti P, Thiemermann C: Glycogen synthase kinase-3beta inhibition attenuates the development of ischaemia/ reperfusion injury of the gut. Intensive Care Med 2007;33:880-893.

92 Costantino G, Cuzzocrea S, Mazzon E, Caputi AP: Protective effects of melatonin in zymosan-activated plasma-induced paw inflammation. Eur J Pharmacol 1998;363:57-63.

93 Impellizzeri D, Esposito E, Di Paola R, Ahmad A, Campolo M, Peli A, Morittu VM, Britti D, Cuzzocrea S: Palmitoylethanolamide and luteolin ameliorate development of arthritis caused by injection of collagen type II in mice. Arthritis Res Ther 2013;15:R192.

94 Marklund S, Marklund G: Involvement of the superoxide anion radical in the autoxidation of pyrogallol and a convenient assay for superoxide dismutase. Eur J Biochem 1974;47:469-474.

95 Aebi H: Catalase in vitro. Methods Enzymol 1984;105:121-126.

96 Moron MS, Depierre JW, Mannervik B: Levels of glutathione, glutathione reductase and glutathione S-transferase activities in rat lung and liver. Biochim Biophys Acta 1979;582:67-78.

97 Arora A, Bhuria V, Hazari PP, Pathak U, Mathur S, Roy BG, Sandhir R, Soni R, Dwarakanath BS, Bhatt AN: Amifostine Analog, DRDE-30, Attenuates Bleomycin-Induced Pulmonary Fibrosis in Mice. Front Pharmacol 2018;9:394.

98 Fusco R, Salinaro AT, Siracusa R, D’Amico R, Impellizzeri D, Scuto M, Ontario ML, Crea R, Cordaro M, Cuzzocrea S: Hidrox ${ }^{\circledR}$ Counteracts Cyclophosphamide-Induced Male Infertility through NRF2 Pathways in a Mouse Model. Antioxidants-Basel 2021;10:778.

99 An X, Sun X, Hou Y, Yang X, Chen H, Zhang P, Wu J: Protective effect of oxytocin on LPS-induced acute lung injury in mice. Sci Rep 2019;9:2836.

100 Sedelis M, Schwarting RK, Huston JP: Behavioral phenotyping of the MPTP mouse model of Parkinson's disease. Behav Brain Res 2001;125:109-125.

101 Cordaro M, Siracusa R, Crupi R, Impellizzeri D, Peritore AF, D’Amico R, Gugliandolo E, Di Paola R, Cuzzocrea S: 2-Pentadecyl-2-Oxazoline Reduces Neuroinflammatory Environment in the MPTP Model of Parkinson Disease. Mol Neurobiol 2018;55:9251-9266.

102 Fleming SM, Mulligan CK, Richter F, Mortazavi F, Lemesre V, Frias C, Zhu C, Stewart A, Gozes I, Morimoto B, Chesselet MF: A pilot trial of the microtubule-interacting peptide (NAP) in mice overexpressing alphasynuclein shows improvement in motor function and reduction of alpha-synuclein inclusions. Mol Cell Neurosci 2011;46:597-606.

103 Siracusa R, Paterniti I, Cordaro M, Crupi R, Bruschetta G, Campolo M, Cuzzocrea S, Esposito E: Neuroprotective Effects of Temsirolimus in Animal Models of Parkinson's Disease. Mol Neurobiol 2018;55:2403-2419.

104 Araki T, Kumagai T, Tanaka K, Matsubara M, Kato H, Itoyama Y, Imai Y: Neuroprotective effect of riluzole in MPTP-treated mice. Brain Res 2001;918:176-181.

105 Paterniti I, Campolo M, Siracusa R, Cordaro M, Di Paola R, Calabrese V, Navarra M, Cuzzocrea S, Esposito E: Liver X receptors activation, through T0901317 binding, reduces neuroinflammation in Parkinson's disease. PLoS One 2017;12:e0174470.

106 Pellow S, Chopin P, File SE, Briley M: Validation of open:closed arm entries in an elevated plus-maze as a measure of anxiety in the rat. J Neurosci Methods 1985;14:149-167.

107 Papale A, d'Isa R, Menna E, Cerovic M, Solari N, Hardingham N, Cambiaghi M, Cursi M, Barbacid M, Leocani L, Fasano S, Matteoli M, Brambilla R: Severe Intellectual Disability and Enhanced Gamma-Aminobutyric Acidergic Synaptogenesis in a Novel Model of Rare RASopathies. Biol Psychiatry 2017;81:179-192.

108 Prut L, Belzung C: The open field as a paradigm to measure the effects of drugs on anxiety-like behaviors: a review. Eur J Pharmacol 2003;463:3-33.

109 Crupi R, Cambiaghi M, Spatz L, Hen R, Thorn M, Friedman E, Vita G, Battaglia F: Reduced adult neurogenesis and altered emotional behaviors in autoimmune-prone B-cell activating factor transgenic mice. Biol Psychiatry 2010;67:558-566.

110 Barnes CA: Memory deficits associated with senescence: a neurophysiological and behavioral study in the rat. J Comp Physiol Psychol 1979;93:74-104.

111 Hay J, Shahzeidi S, Laurent G: Mechanisms of bleomycin-induced lung damage. Arch Toxicol 1991;65:81-94.

112 Zhang HY, Gharaee-Kermani M, Zhang K, Karmiol S, Phan SH: Lung fibroblast alpha-smooth muscle actin expression and contractile phenotype in bleomycin-induced pulmonary fibrosis. Am J Pathol 1996;148:527-537. 


\section{Cellular Physiology Cell Physiol Biochem 2021;55:704-725 \begin{tabular}{ll|l|l|l}
\hline DOI: 10.33594/000000471 & ( 2021 The Author(s). Published by \\
\hline
\end{tabular} and Biochemistry Published online: 18 November 2021 Cell Physiol Biochem Press GmbH\&Co. KG

113 Pelgrim CE, Peterson JD, Gosker HR, Schols A, van Helvoort A, Garssen J, Folkerts G, Kraneveld AD: Psychological co-morbidities in COPD: Targeting systemic inflammation, a benefit for both? Eur J Pharmacol 2019;842:99-110.

114 Filipov NM, Stewart MA, Carr RL, Sistrunk SC: Dopaminergic toxicity of the herbicide atrazine in rat striatal slices. Toxicology 2007;232:68-78.

115 Ogawa N, Hirose Y, Ohara S, Ono T, Watanabe Y: A simple quantitative bradykinesia test in MPTP-treated mice. Res Commun Chem Pathol Pharmacol 1985;50:435-441.

116 United States Environmental Protection Agency (EPA): Atrazine Monitoring Program Data and Results. 2008. URL: https://www.epa.gov/ingredients-used-pesticide-products/atrazine-monitoring-programdata-and-results.

117 Ackerman F: The economics of atrazine. Int J Occup Environ Health 2007;13:437-445.

118 Pohl H, Kolman J: Interaction profile for atrazine, deethylatrazine, diazinon, nitrate and simazine. Agency for Toxic Substances and Disease Registry (ATSDR), Atlanta, Georgia: US: Department of Health and Human Services, Public Health, 2006.

119 Kavlock R: Overview of endocrine disruptor research activity in the United States. Chemosphere 1999;39:1227-1236.

120 Munger R, Isacson P, Hu S, Burns T, Hanson J, Lynch CF, Cherryholmes K, Van Dorpe P, Hausler WJ, Jr.: Intrauterine growth retardation in Iowa communities with herbicide-contaminated drinking water supplies. Environ Health Perspect 1997;105:308-314.

121 Arbuckle TE, Lin Z, Mery LS: An exploratory analysis of the effect of pesticide exposure on the risk of spontaneous abortion in an Ontario farm population. Environ Health Perspect 2001;109:851-857.

122 Hayes TB, Collins A, Lee M, Mendoza M, Noriega N, Stuart AA, Vonk A: Hermaphroditic, demasculinized frogs after exposure to the herbicide atrazine at low ecologically relevant doses. Proc Natl Acad Sci U S A 2002;99:5476-5480.

123 Swan SH: Semen quality in relation to pesticide exposure in Missouri males. Mo Med 2003;100:554.

124 Swan SH, Kruse RL, Liu F, Barr DB, Drobnis EZ, Redmon JB, Wang C, Brazil C, Overstreet JW, Study for Future Families Research G: Semen quality in relation to biomarkers of pesticide exposure. Environ Health Perspect 2003;111:1478-1484.

125 Sauleda J, Nunez B, Sala E, Soriano JB: Idiopathic Pulmonary Fibrosis: Epidemiology, Natural History, Phenotypes. Med Sci (Basel) 2018;6:110.

126 Abarikwu SO: Protective effect of quercetin on atrazine-induced oxidative stress in the liver, kidney, brain, and heart of adult wistar rats. Toxicol Int 2014;21:148-155.

127 Mizota K, Ueda H: Endocrine disrupting chemical atrazine causes degranulation through Gq/11 proteincoupled neurosteroid receptor in mast cells. Toxicol Sci 2006;90:362-368.

128 Jestadi DB, Phaniendra A, Babji U, Srinu T, Shanmuganathan B, Periyasamy L: Effects of short term exposure of atrazine on the liver and kidney of normal and diabetic rats. J Toxicol 2014;2014:536759.

129 Kisseleva T, Brenner DA: Fibrogenesis of parenchymal organs. Proc Am Thorac Soc 2008;5:338-342.

130 Kisseleva T, Brenner DA: Mechanisms of fibrogenesis. Exp Biol Med (Maywood) 2008;233:109-122.

131 Moore BB, Fry C, Zhou Y, Murray S, Han MK, Martinez FJ, Flaherty KR, The CI: Inflammatory leukocyte phenotypes correlate with disease progression in idiopathic pulmonary fibrosis. Front Med 2014;1:56.

132 Le TT, Karmouty-Quintana H, Melicoff E, Le TT, Weng T, Chen NY, Pedroza M, Zhou Y, Davies J, Philip K, Molina J, Luo F, George AT, Garcia-Morales LJ, Bunge RR, Bruckner BA, Loebe M, Seethamraju H, Agarwal SK, Blackburn MR: Blockade of IL-6 Trans signaling attenuates pulmonary fibrosis. J Immunol 2014;193:37553768.

133 Martinez JA, King TE, Jr., Brown K, Jennings CA, Borish L, Mortenson RL, Khan TZ, Bost TW, Riches DW: Increased expression of the interleukin-10 gene by alveolar macrophages in interstitial lung disease. Am J Physiol 1997;273:L676-683.

134 Badham HJ, Renaud SJ, Wan J, Winn LM: Benzene-initiated oxidative stress: Effects on embryonic signaling pathways. Chem Biol Interact 2010;184:218-221.

135 Shono T, Taguchi T: Short-time exposure to mono-n-butyl phthalate (MBP)-induced oxidative stress associated with DNA damage and the atrophy of the testis in pubertal rats. Environ Sci Pollut Res Int 2014;21:3187-3190. 


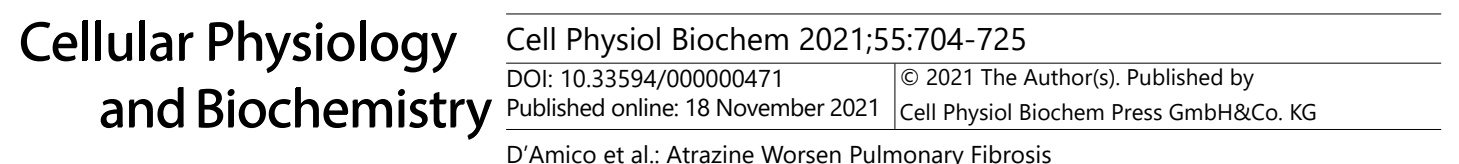

136 Sulkowski ZL, Chen T, Midha S, Zavacki AM, Sajdel-Sulkowska EM: Maternal thimerosal exposure results in aberrant cerebellar oxidative stress, thyroid hormone metabolism, and motor behavior in rat pups; sexand strain-dependent effects. Cerebellum 2012;11:575-586.

137 Neier K, Marchlewicz EH, Dolinoy DC, Padmanabhan V: Assessing Human Health Risk to Endocrine Disrupting Chemicals: a Focus on Prenatal Exposures and Oxidative Stress. Endocr Disruptors (Austin) 2015;3:e1069916.

138 Ma Q: Role of nrf2 in oxidative stress and toxicity. Annu Rev Pharmacol Toxicol 2013;53:401-426.

139 Kokturk N, Polatli M, Oguzulgen IK, Saleemi S, Al Ghobain M, Khan J, Doble A, Tariq L, Aziz F, El Hasnaoui A: Adherence to COPD treatment in Turkey and Saudi Arabia: results of the ADCARE study. Int J Chron Obstruct Pulmon Dis 2018;13:1377-1388.

140 Hilmarsen CW, Wilke S, Engan H, Spruit MA, Rodenburg J, Janssen DJ, Steinshamn S, Jones PW, Wouters EF, Oldervoll L, Franssen FM: Impact of symptoms of anxiety and depression on COPD Assessment Test scores. Eur Respir J 2014;43:898-900.

141 Lou P, Zhu Y, Chen P, Zhang P, Yu J, Wang Y, Chen N, Zhang L, Wu H, Zhao J: Interaction of depressive and anxiety symptoms on the mortality of patients with COPD: a preliminary study. COPD 2014;11:444-450.

$142 \mathrm{Hu} \mathrm{S}$, Li L, Wu X, Liu Z, Fu A: Post-surgery anxiety and depression in prostate cancer patients: prevalence, longitudinal progression, and their correlations with survival profiles during a 3-year follow-up. Ir J Med Sci 2021;190:1363-1372.

143 Yousuf A, Musa R, Isa MLM, Arifin SRM: Anxiety and Depression Among Women Living with HIV: Prevalence and Correlations. Clin Pract Epidemiol Ment Health 2020;16:59-66.

144 Shao R, He P, Ling B, Tan L, Xu L, Hou Y, Kong L, Yang Y: Prevalence of depression and anxiety and correlations between depression, anxiety, family functioning, social support and coping styles among Chinese medical students. BMC Psychol 2020;8:38.

145 Hajduk M, Heretik A, Jr., Vaseckova B, Forgacova L, Pecenak J: Prevalence and correlations of depression and anxiety among Slovak college students. Bratisl Lek Listy 2019;120:695-698.

146 Lou P, Zhu Y, Chen P, Zhang P, Yu J, Zhang N, Chen N, Zhang L, Wu H, Zhao J: Prevalence and correlations with depression, anxiety, and other features in outpatients with chronic obstructive pulmonary disease in China: a cross-sectional case control study. BMC Pulm Med 2012;12:53.

147 Bayram N, Bilgel N: The prevalence and socio-demographic correlations of depression, anxiety and stress among a group of university students. Soc Psychiatry Psychiatr Epidemiol 2008;43:667-672.

148 Singh JM, Palda VA, Stanbrook MB, Chapman KR: Corticosteroid therapy for patients with acute exacerbations of chronic obstructive pulmonary disease: a systematic review. Arch Intern Med 2002;162:2527-2536.

149 Pumar MI, Gray CR, Walsh JR, Yang IA, Rolls TA, Ward DL: Anxiety and depression-Important psychological comorbidities of COPD. J Thorac Dis 2014;6:1615-1631.

150 Kunik ME, Roundy K, Veazey C, Souchek J, Richardson P, Wray NP, Stanley MA: Surprisingly high prevalence of anxiety and depression in chronic breathing disorders. Chest 2005;127:1205-1211. 